San Jose State University

SJSU ScholarWorks

Master's Theses

Master's Theses and Graduate Research

Summer 2012

\title{
Hydrostratigraphy of the Shallow Aquifer in the Niles Cone Groundwater Basin
}

Ramon W. Cioco

San Jose State University

Follow this and additional works at: https://scholarworks.sjsu.edu/etd_theses

\section{Recommended Citation}

Cioco, Ramon W., "Hydrostratigraphy of the Shallow Aquifer in the Niles Cone Groundwater Basin" (2012). Master's Theses. 4192.

DOI: https://doi.org/10.31979/etd.b6sy-fb6j

https://scholarworks.sjsu.edu/etd_theses/4192

This Thesis is brought to you for free and open access by the Master's Theses and Graduate Research at SJSU ScholarWorks. It has been accepted for inclusion in Master's Theses by an authorized administrator of SJSU ScholarWorks. For more information, please contact scholarworks@sjsu.edu. 


\title{
HYDROSTRATIGRAPHY OF THE SHALLOW AQUIFER
}

\section{IN THE NILES CONE GROUNDWATER BASIN}

\author{
A Thesis \\ Presented to \\ The Faculty of the Department of Geology \\ San José State University \\ In Partial Fulfillment \\ of the Requirements for the Degree \\ Master of Science
}

by

Ramon W. Cioco

August 2012 
(C)2012

Ramon W. Cioco

ALL RIGHTS RESERVED 


\section{HYDROSTRATIGRAPHY OF THE SHALLOW AQUIFER IN THE NILES CONE GROUNDWATER BASIN}

by

Ramon W. Cioco

APPROVED FOR THE DEPARTMENT OF GEOLOGY

SAN JOSE STATE UNIVERSITY

August 2012

Dr. June A. Oberdorfer

Dr. David W. Andersen

Mr. Douglas T. Young
Department of Geology

Department of Geology

Alameda County Water District 


\begin{abstract}
HYDROSTRATIGRAPHY OF THE SHALLOW AQUIFER

IN THE NILES CONE GROUNDWATER BASIN
\end{abstract}

\author{
by Ramon W. Cioco
}

The Shallow Aquifer in the Niles Cone Groundwater Basin, southern Alameda County, California, can act as a migration pathway for surface contaminants into the underlying Newark Aquifer, a source of water supply. This study, we used 110 borehole logs from Alameda County Water District's database to classify the hydrostratigraphy of the uppermost geologic deposits, and utilized the Rockworks $2002^{\circledR}$ software package to define regions sensitive to surface contamination.

The Shallow Aquifer is a discontinuous and localized deposit covering approximately $40 \%$ of the study area. About $15 \%$ of the Shallow Aquifer is exposed to surface contamination, and roughly $15 \%$ is hydraulically connected to the Newark Aquifer. Combining both sensitive areas indicated that the Forebay and its vicinity are the sites most vulnerable to contamination. The spatial distribution of aquifer sediment indicated that two stream channels deposited the Shallow Aquifer, the larger being Alameda Creek and the smaller Dry Creek. Some deposition occurred when San Francisco Bay was at least $12 \mathrm{~m}$ below its present level sometime during the last glacial low stand and continued up to the present, at least in the Forebay area. 


\section{ACKNOWLEDGEMENTS}

I would like to express my deepest and sincerest gratitude to my thesis advisor, Dr. June A. Oberdorfer. She has been supportive of me since my first day of school at SJSU. Her encouragement to further pursue my studies inspired my lifelong dream to earn a Master of Science degree. Without her invaluable support, guidance and assistance, this thesis could not have been made possible. Her patience during the research greatly helped challenge me to work hard in completing my thesis.

I would like also to acknowledge Mr. Douglas T. Young of the Alameda County Water District, who came up with the idea on this research study and gave me the opportunity to work on it. Doug Young provided the necessary reference materials for the study including the software, Rockworks $2002^{\circledR}$, which was used in the evaluation of the hydrostratigraphy. I would also like to thank my professor, Dr. David W. Andersen, for his thorough reviews which significantly improved the manuscript. Thanks go to Ginny Smith and her technical staff who were always available to install the software in the computer laboratory.

Most of all, I would like to thank my wife, Priscilla, for her motivation, encouragement, and financial support in my studies at SJSU. I send a special thank you to my sons, Ryan and Raymond, who always inquired about my studies and also motivated me to finish my thesis. 


\section{TABLE OF CONTENTS}

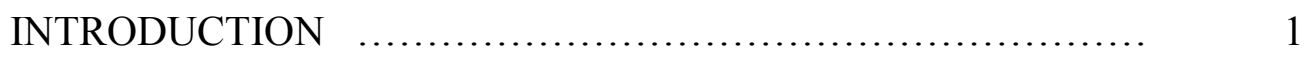

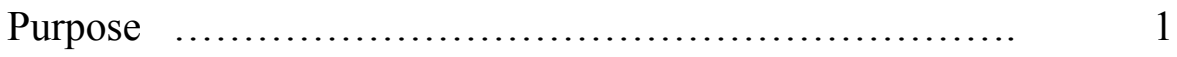

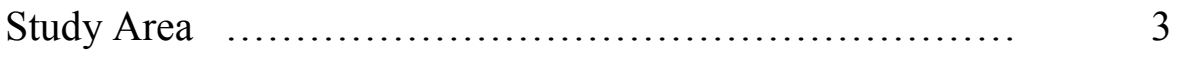

GEOLOGY AND HYDROGEOLOGY $\ldots \ldots \ldots \ldots \ldots \ldots \ldots \ldots \ldots . \ldots$

Regional Geologic Setting $\quad \ldots . \ldots \ldots \ldots \ldots \ldots \ldots \ldots \ldots \ldots . \ldots \ldots$

Brief Description of the Geologic History and

Stratigraphic Deposition $\quad \ldots \ldots \ldots \ldots \ldots \ldots \ldots \ldots \ldots \ldots \ldots \ldots . \ldots \ldots$

Hydrogeologic Setting $\quad \ldots . \ldots \ldots \ldots \ldots \ldots \ldots \ldots \ldots \ldots \ldots . . . \ldots \ldots$

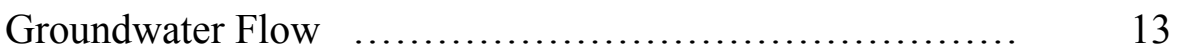



ACWD Groundwater Use $\quad \ldots \ldots \ldots \ldots \ldots \ldots \ldots \ldots \ldots \ldots . . . \ldots \ldots$

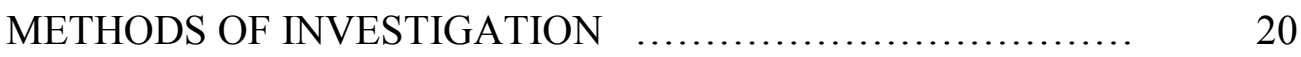

RESULTS ................................................ 29



Stratigraphic Surface Maps $\quad \ldots \ldots \ldots \ldots \ldots \ldots \ldots \ldots \ldots \ldots . \ldots \ldots$ 


\section{LIST OF FIGURES}

Figure



2. Simplified Geologic Map of the Area $\ldots . \ldots \ldots \ldots \ldots \ldots \ldots \ldots . \ldots . \ldots$

3. Groundwater Elevation Map of 2010 .................... 15

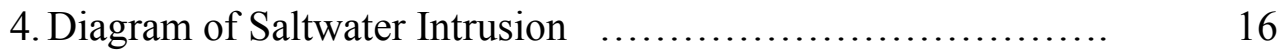

5. Map showing Sources of Water Supply $\ldots \ldots \ldots \ldots \ldots \ldots \ldots . . . \ldots$



7. Location of Stratigraphic Cross-section Lines $\ldots \ldots \ldots \ldots \ldots . . . . . .26$

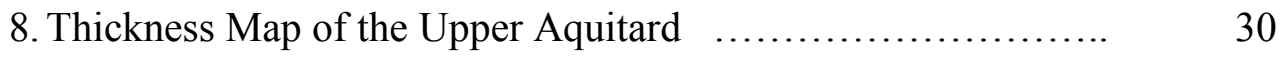

9. Thickness Map of the Shallow Aquifer $\ldots . \ldots \ldots \ldots \ldots \ldots \ldots . . . . . .632$

10. Thickness Map of the Newark Aquitard $\ldots . . . \ldots \ldots \ldots \ldots \ldots . . . . . .33$

11. Stratigraphic Surface Map of the Shallow Aquifer $\ldots . . . . . . . . \quad 35$

12. Sea-level Changes in Southern San Francisco Bay during Holocene Epoch $\quad \ldots \ldots \ldots \ldots \ldots \ldots \ldots \ldots \ldots \ldots \ldots \ldots \ldots . . . \ldots \ldots$

13. Stratigraphic Surface Map of the Newark Aquitard ........... 37

14. Stratigraphic Surface Map of the Newark Aquifer $\ldots . \ldots \ldots \ldots . . . . \quad 38$

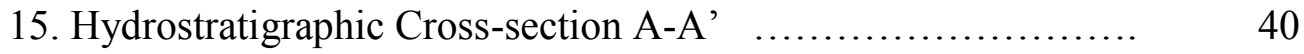

16. Hydrostratigraphic Cross-section B-B' $\quad \ldots \ldots \ldots \ldots \ldots \ldots \ldots \ldots . . \ldots . \ldots$

17. Hydrostratigraphic Cross-section $\mathrm{C}-\mathrm{C}{ }^{\prime} \quad \ldots \ldots \ldots \ldots \ldots \ldots \ldots \ldots . \ldots \ldots$

18. Hydrostratigraphic Cross-section D-D' $\ldots \ldots \ldots \ldots \ldots \ldots \ldots \ldots . \ldots \ldots$ 
19. Hydrostratigraphic Cross-section E-E' $\ldots \ldots \ldots \ldots \ldots \ldots \ldots \ldots \ldots . \ldots \ldots$

20. Map of Areas Where the Upper Aquitard Is Thin or Absent $\ldots \quad 44$

21. Map of Areas Where the Newark Aquitard Is Thin or Absent .. $\quad 46$

22. Map of Areas Most Sensitive to Contamination of

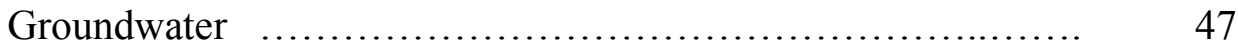

23. Map of Inferred Paleodrainage Channels $\ldots \ldots \ldots \ldots \ldots \ldots \ldots \ldots . . . . . .48$ 


\section{LIST OF TABLES}

Table

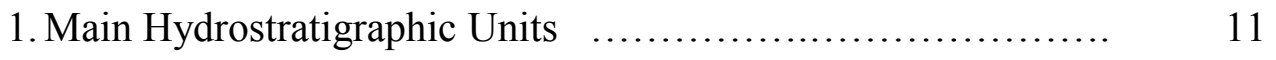

2. Hydrostratigraphic Interpretation for Typical

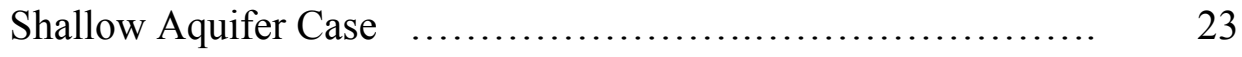

3. Hydrostratigraphic Interpretation for Exposed

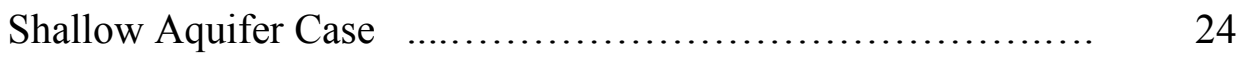

4. Hydrostratigraphic Interpretation for All

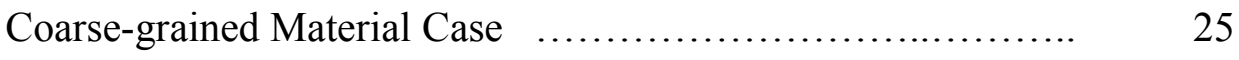




\section{INTRODUCTION}

\section{Purpose}

The Alameda County Water District's (ACWD) service area generally sits on top of the Niles Cone Groundwater Basin. ACWD provides almost half of its water supply from groundwater wells. Figure 1 shows the map of the study area illustrating the boundaries of the ACWD and the Niles Cone Groundwater Basin. Due to uncontrolled groundwater pumping beginning in the early $20^{\text {th }}$ century, the Niles Cone Basin experienced an overdraft of groundwater that ultimately led to saltwater encroachment from San Francisco Bay (ACWD, 2010a). A remnant of the saltwater intrusion still remains to date.

Although many hydrogeologic studies have been performed in the area, the Shallow Aquifer deposits in the upper $15 \mathrm{~m}$ of the Niles Cone Groundwater Basin have not been investigated, nor has the hydraulic connection of the Shallow Aquifer with the underlying main aquifers been established. As part of the program to conserve the Niles Cone Groundwater Basin, the ACWD expressed a concern about the Shallow Aquifer's potential as a migration pathway of possible contaminants from residential, commercial and industrial establishments in the area. 

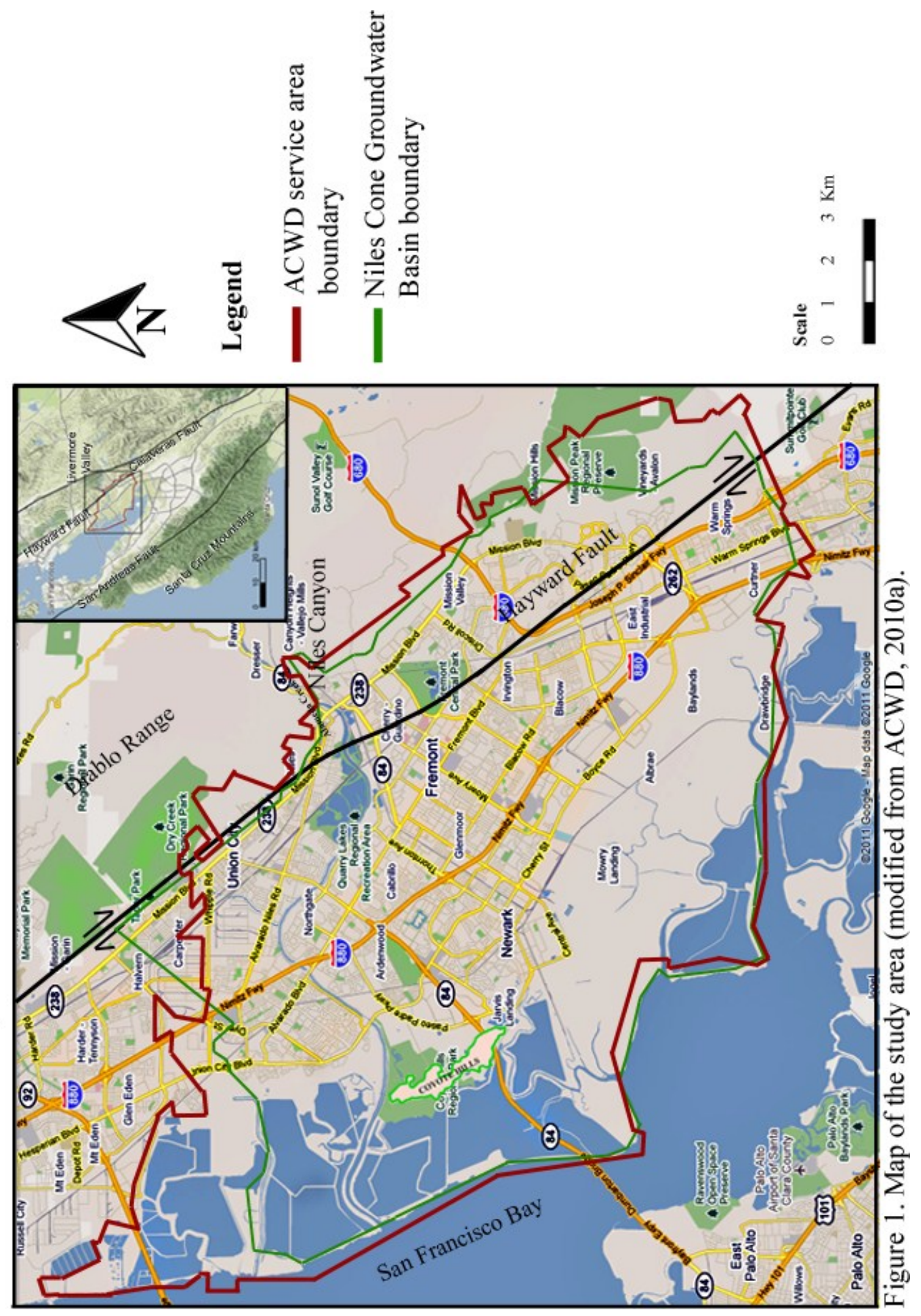
The purpose of this hydrostratigraphic study of the uppermost sections of the Niles Cone Basin was to define the areal extent of the shallow, coarse-grained materials as well as their generalized hydraulic connection with the underlying regional aquifers. The results of this study also served to update and improve the Niles Cone Groundwater Basin model developed by ACWD. Additionally, it provided insight into the recent depositional history in the Niles Cone area.

\section{Study Area}

The study area encompassed the area west of the Hayward fault section of the Niles Cone Groundwater Basin, bounded on the north by the City of Hayward, on the south by the City of Milpitas, on the east by the Hayward fault and on the west by San Francisco Bay. ACWD's service area includes the cities of Fremont, Newark, and Union City. Excluded from this investigation were the portions of ACWD's service area located east of the Hayward fault, because of the absence of the Shallow Aquifer in that area. The study area comprised that portion of the basin for which borehole data were available and has an areal extent of about $130 \mathrm{~km}^{2}$.

The study area gently slopes westward from the foot of the Diablo Range toward the shoreline of San Francisco Bay and Coyote Hills; the latter prominently rise above the sloping plain with a maximum elevation of $88 \mathrm{~m}$ above sea level.

The climate of the area is classified as dry-summer, subtropical, or Mediterranean under the Koppen climate classification system (FAO, 1999): hot and dry during the 
summers and moderate temperatures and rainy weather during the winters. The mean annual rainfall in the area is $37.7 \mathrm{~cm}$ with the wettest period from November to March. The average annual temperature is $15.5^{\circ} \mathrm{C}$; the warmest month of the year is August, with an average maximum temperature of $26^{\circ} \mathrm{C}$, and the coldest month is December, with an average minimum temperature of $6^{\circ} \mathrm{C}$ (NOAA, 2004).

Cutting across the study area is Alameda Creek, the main drainage channel. It drains the Livermore Valley and exits Niles Canyon at the base of Diablo Range, flowing westward into San Francisco Bay. The Niles Cone Groundwater Basin is cut at the eastern boundary by the northwesterly trending Hayward fault, which skirts along the foot of the Diablo Range. 


\section{GEOLOGY AND HYDROGEOLOGY}

\section{Regional Geologic Setting}

The landscape of San Francisco Bay region is shaped by the tectonic processes that generally control the area. The northwesterly oriented San Francisco Bay depression is a structural trough down-warped by the movement of the parallel northwesterly

oriented active faults along its edges, the San Andreas fault on the west and the Hayward fault on the east. The inception of these two faults probably developed in the transition period during the shifting of the tectonic setting in the western edge of the North American continental plate from convergent margin to transform margin about $10 \mathrm{Ma}$ (Graham et al., 1984). Flanking the depression are the northwesterly trending mountain ranges, the Santa Cruz Mountains on the west and the Diablo Range on the east. The evolution of the modern coastal ranges was likewise linked to the development of the transform boundary between the North American and Pacific plates (Graham et al., 1984).

The rock comprising the basement of the depression is the Franciscan Complex of Mesozoic age, which has igneous and metamorphic origins. Overlying the Franciscan rock complex are Mesozoic and several Cenozoic marine units and deposits of mostly coarse-grained alluvial sediments from the eroded mountainsides; these have been carried by various streams in the region (CRWQCB, 2003). Within the continental alluvial 
deposits are beds of fine-grained clayey and silty sediments. The thickness of the sediments filling the San Francisco Bay depression varies along its axis, the thickest being in the south in Santa Clara Valley at more than $460 \mathrm{~m}$ to less than $150 \mathrm{~m}$ near the Coyote Hills (CDWR, 1967). A simplified geologic map of the study area is shown in Figure 2 .

\section{Brief Description of the Geologic History and Stratigraphic Deposition}

The modern San Francisco Bay region was subjected to intense geological activity in the Quaternary period. The compressional forces from the northeast and southwest created intense folding, faulting, uplift and downwarped basins in the northwest-southeast oriented Costal Ranges (Brown, 1990). The downwarped basin containing San Francisco Bay and Santa Clara Valley began to subside at that time, between 1 and 0.5 Ma (Rogers and Figuers, 1992). During the gradual subsiding of the San Francisco Bay region, estuarine, alluvial materials, and freshwater swamp sediments were deposited on the valley depression (Brown, 1990). These alluvial deposits that filled the valley floor emanated from the Santa Cruz Mountains and Diablo Range.

In contrast to the uplift of the coastal ranges during the Quaternary period, the valley depression gradually continued to subside between the San Andreas and Hayward faults. However, the valley floor did not subside uniformly. In the vicinity of the 

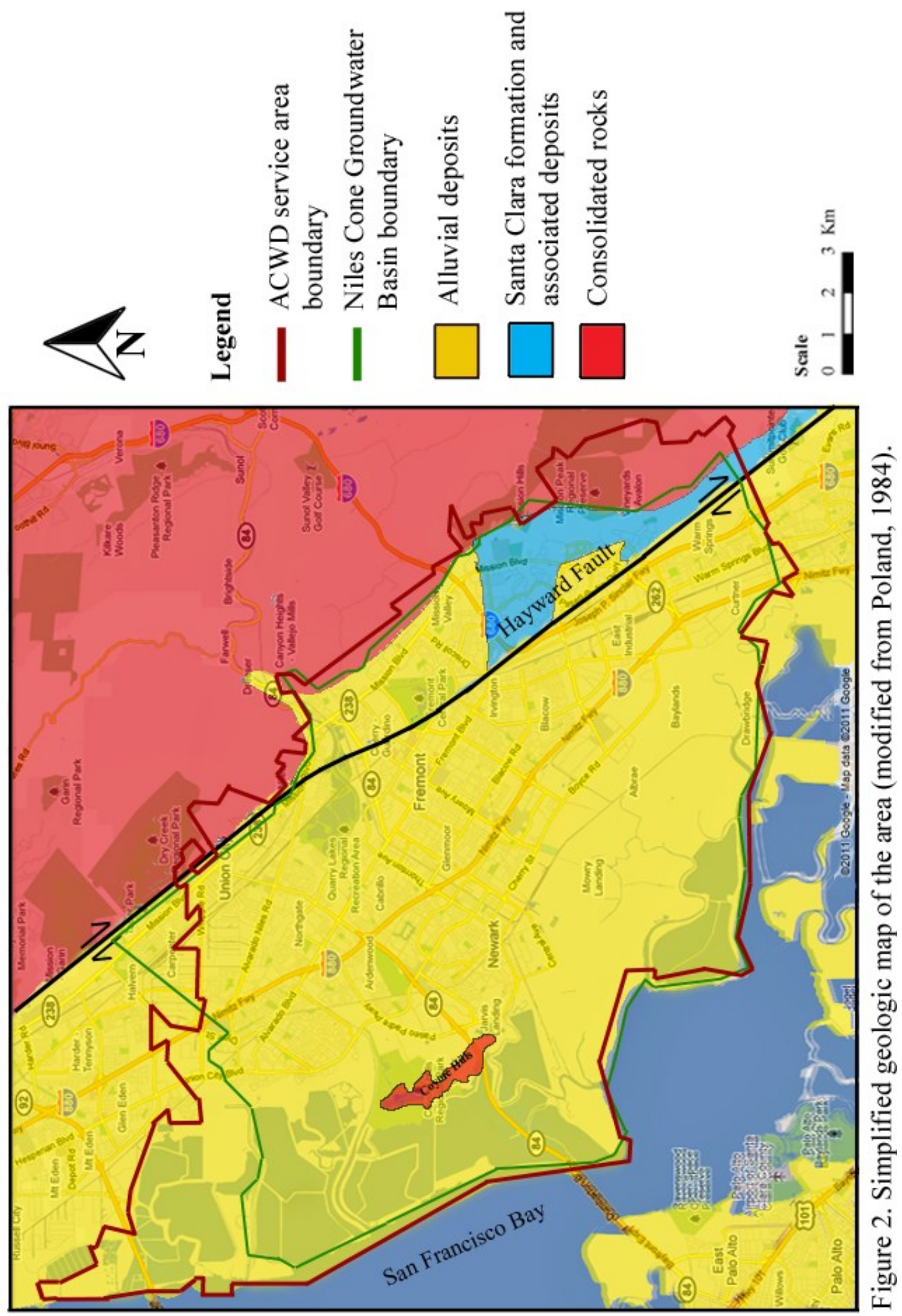
Oakland International Airport, the bedrock elevation is $305 \mathrm{~m}$ below sea level (Rogers, and Figuers, 1992), whereas the bedrock is exposed in the Coyote Hills.

Aside from uplift and erosion, sediment deposition in the Bay Area was also influenced by climate change during the Quaternary period. Koltermann and Gorelick (1992) suggested that coarse-grained layers indicate colder and wetter periods during glacial stages, whereas fine-grained layers indicate warmer and drier periods during interglacial stages. The widespread gravel and sand layers such as the Newark, Centerville, Fremont, and Deep Aquifers were probably deposited during glacial stages, and the fine-grained layers including the Newark, Irvington, and Mission aquitards were probably deposited during the interglacial stages. However, this theory was put into question with the USGS drill-hole data in Santa Clara Valley (Newhouse et al., 2004). Drilling there was conducted in 2000 to 2003.

The changes of global eustatic sea level correspond to the vast quantities of water that were accumulated in the continental ice sheets during glacial stages and the amount of water released when ice melted during interglacial stages. During glacial stages, sea level was lowered by as much as $120 \mathrm{~m}$ below present sea level, and the shorelines were about $75 \mathrm{~km}$ west of the present San Francisco coast. During interglacial stages, sea level rose and in the late Pleistocene probably reached the Coyote Hills area (Atwater et al., 1977). 


\section{Hydrogeologic Setting}

The Niles Cone Groundwater Basin is composed of an alluvial fan formed by Alameda Creek as it issues out from the Diablo Range and flows towards San Francisco Bay. The alluvial fan, which began to form 600,000 years ago, consists of Quaternary gravels and sands derived from Mesozoic and Tertiary shale and sandstone from the Diablo Range (Koltermann and Gorelick, 1992). Aquifers in the Niles Cone basin are composed generally of sandy and gravelly deposits and have higher permeability whereas the aquitards, which consist mainly of clayey and silty sediments, have lower permeability (ACWD, 2010a).

The Hayward fault, which traverses the study area along the base of the Diablo Range, serves as a low-permeability barrier to the westward flow of groundwater. It creates sharp water-level differences between the wells to the east and west of the fault (ACWD, 2010a). ACWD's 2010 water-level measurements indicated a head difference of about $7 \mathrm{~m}$ across the fault (ACWD, 2010a), although the recorded maximum difference of $29 \mathrm{~m}$ was observed in October 21, 1958 (CWDR, 1967). For this reason, the Niles Cone Groundwater Basin was divided into two sub-basins: the Above Hayward Fault (AHF) and the Below Hayward Fault (BHF). The AHF sub-basin consists of highly permeable, coarse-grained deposits, whereas the BHF sub-basin is composed of alternating beds of aquifers and aquitards. Some of the thin clay layers within the aquifer beds were probably deposited as overbank deposits as stream channels shifted. Most of the aquifers in the BHF are confined (CDWR, 1967). 
In the study area (BHF sub-basin), three main aquifers in the upper $120 \mathrm{~m}$ supply most of the water to wells for domestic, public, and industrial use. In descending order, they are known as the Newark, Centerville, and Fremont aquifers. Aquifers below $120 \mathrm{~m}$ are also known to exist, and they are referred to as the Deep Aquifers (ACWD, 2010a). Deposited between the main aquifers are fine-grained layers known as the Irvington Aquitard, separating the Newark and Centerville aquifers, and the Mission Aquitard, separating the Centerville and Fremont aquifers. Within the uppermost strata above the Newark Aquifer, referred to as the Newark Aquitard, exists a shallow and discontinuous coarse-grained deposit, known as the Shallow Aquifer. There are no historical records on the effect of saltwater intrusion within the Shallow aquifer in the study area. Table 1 lists the main hydrostratigraphic units, their thickness ranges and the depths at which they can be encountered.

Lying above the Newark Aquifer and covering almost the entire study area is the Newark Aquitard. Its thickness varies from location to location, but it is generally thicker near the bay shore and totally absent at the apex of the alluvial fan (CDWR, 1967). The thickness of the Newark aquitard plays a prominent role in the vertical movement of surface water to underlying aquifers. In areas where it is thick, downward movement of surface water is retarded and, conversely, where it is thin or absent the movement is unhindered.

The uppermost main aquifer in the study area is the Newark Aquifer, which underlies the Newark Aquitard. It is an extensive, permeable, gravel and sand layer, and its top can be encountered from depths of 12 to $42 \mathrm{~m}$ below the ground surface (bgs). In 
TABLE 1. MAIN HYDROSTRATIGRAPHIC UNITS

\begin{tabular}{lcc}
\hline $\begin{array}{l}\text { Hydrostratigraphic Unit } \\
\text { (top to bottom) }\end{array}$ & $\begin{array}{c}\text { Encounterd at depths } \\
(\mathrm{m} \mathrm{bgs})\end{array}$ & $\begin{array}{c}\text { Thickness range } \\
(\mathrm{m})\end{array}$ \\
\hline Newark Aquitard & $0-15$ & $0-22$ \\
Newark Aquifer & $12-42$ & $6-42$ \\
Irvington Aquitard & $18-55$ & $10-35$ \\
Centerville Aquifer & $55-61$ & $3-30$ \\
Mission Aquitard & $\begin{array}{c}\text { (top depth range) } \\
58-90\end{array}$ & $7-27$ \\
Fremont Aquifer & $90-120$ & $5-23$ \\
Deep Aquifers & $>120$ & $>15$ \\
\hline
\end{tabular}

Note: Data from CWDR (1968) and ACWD (2010b).

some areas permeable sediment overlies the Newark Aquifer. The Newark aquifer is found in almost the entire study area except at the Coyote Hills and a few locations in the southeast. Its thickness ranges from $6 \mathrm{~m}$ near the shoreline of the bay to more than $42 \mathrm{~m}$ near the Hayward fault (ACWD, 2010a). Previous studies (CWDR, 1967 and Maslonkowki, 1988) in the area indicated that the Newark aquifer extends beneath the Bay and underneath the western side of the Bay in the San Mateo area. Thus, it serves as the primary pathway of saltwater migration from the Bay toward the interior of the basin to the east (CDWR, 1967). The aquifer is not a single continuous layer but rather sand and gravel layers separated by thin interbeds of clay and silt (Maslonkowski, 1988).

Below the Newark Aquifer is the fine-grained layer referred to as the Irvington Aquitard. The aquitard serves as a protective barrier to vertical saltwater migration from 
the overlying Newark Aquifer. This was demonstrated by an exploratory well drilled into the underlying aquifer at the middle of the bay. The well yielded better quality water than did the overlying Newark aquifer. This indicates the impermeable nature of the Irvington Aquitard (CDWR, 1967). This condition has also been shown by the results of the investigation conducted by ACWD in their saltwater intrusion monitoring program in 2010 (ACWD, 2010b). That study yielded permeability results for the Irvington Aquitard ranging from $5.36 \times 10^{-4}$ to $1.33 \times 10^{-8} \mathrm{~cm} / \mathrm{sec}$.

Underlying the Irvington Aquitard is the Centerville Aquifer, the top of which can be encountered from depths of 55 to $61 \mathrm{~m}$ bgs. Its thickness ranges from 3 to $30 \mathrm{~m}$, and the aquifer can be found over almost the entire study area except at the Coyote Hills. Like the Newark Aquifer, the Centerville Aquifer exists beneath the Bay and into its western margins. Wells drilled in Ravenswood, East Palo Alto, tapped this aquifer (CDWR, 1967).

The Mission Aquitard is a thick, extensive clay layer below the Centerville Aquifer. Permeability testing conducted by ACWD in 2009 yielded values ranging from $4.2 \times 10^{-7}$ to $3.2 \times 10^{-8} \mathrm{~cm} / \mathrm{sec}$. These values indicate that vertical flow is highly restricted (ACWD, 2010b).

The Fremont Aquifer can be found at depths between 90 and $120 \mathrm{~m}$ bgs. Although this aquifer is not well defined, it is generally regarded as more productive than the shallower aquifers (CDWR, 1967). ACWD's Inland Saltwater Intrusion Monitoring Wells Project indicated the thickness range of the Fremont aquifer to be from 5 to $23 \mathrm{~m}$ (ACWD, 2010b). 
Previous studies (CWDR, 1967 and ACWD, 2010a) considered both the Centerville and Fremont aquifers as one water-bearing unit in the entire study area due to insignificant differences in groundwater levels, even with an aquitard separating the two aquifers. However, a recent investigation conducted by ACWD (2010b) indicated otherwise, and there are areas in the basin where hydraulic separation exists between the two aquifers. Monitoring of wells indicated differences in water levels and groundwater chemistry between the two aquifers. The chloride content of water samples from the Centerville Aquifer had maximum values of 660 parts per million (ppm), whereas the Fremont aquifer had maximum values of 1,300 ppm. During that study, water-level monitoring results likewise indicated water elevation differences ranging from 0.1 to 0.3 $\mathrm{m}$ between the two aquifers (ACWD, 2010b).

The main aquifers in the study area merge and act as a single aquifer that extends to the ground surface in the vicinity of the Hayward fault. The region of merged aquifers is referred to as the Forebay area (CDWR, 1967).

\section{Groundwater Flow}

Historical records in the study area from as early as the 1890 s indicate that groundwater from the elevated portions of the basin in the east flows towards the west to San Francisco Bay. Groundwater levels started to decline in the early 1900 s, when the Niles Cone Groundwater Basin was overpumped and the hydraulic gradient in the Newark aquifer reversed landward from the Bay (ACWD, 2010a). Due to the low 
permeability of the Hayward fault, the groundwater levels in AHF aquifer remained above sea level throughout this time period.

In 1962, ACWD implemented programs to restore the groundwater of the Niles Cone to its original conditions, especially in the BHF aquifers. Subsequently, as the aquifers responded to these actions, groundwater levels started to recover. In 1972, water levels were measured to be above sea level, and the hydraulic gradient of the Newark aquifer returned to its original, westward direction (ACWD, 2010a). The latest water level measurements are presented in Figure 3, the groundwater elevation map of 2010.

\section{Water Quality}

Saltwater intrusion has greatly affected the water quality of the Niles Cone Groundwater Basin since the early 1900s. The reversal of the hydraulic gradient in the Newark aquifer allowed saltwater to migrate down into portions of the underlying aquifers. Because the Newark aquifer is the uppermost, main aquifer in the study area, it was the first to be impacted by saltwater intrusion. Subsequently, when the landward migration of the saltwater remained unabated, saltwater reached the Forebay area and resulted in the contamination of the underlying Centerville, Fremont, and Deep aquifers. A generalized diagram illustrating the saltwater intrusion is presented in Figure 4; it shows how the saltwater from the Bay intruded into the underlying aquifers. The AHF 

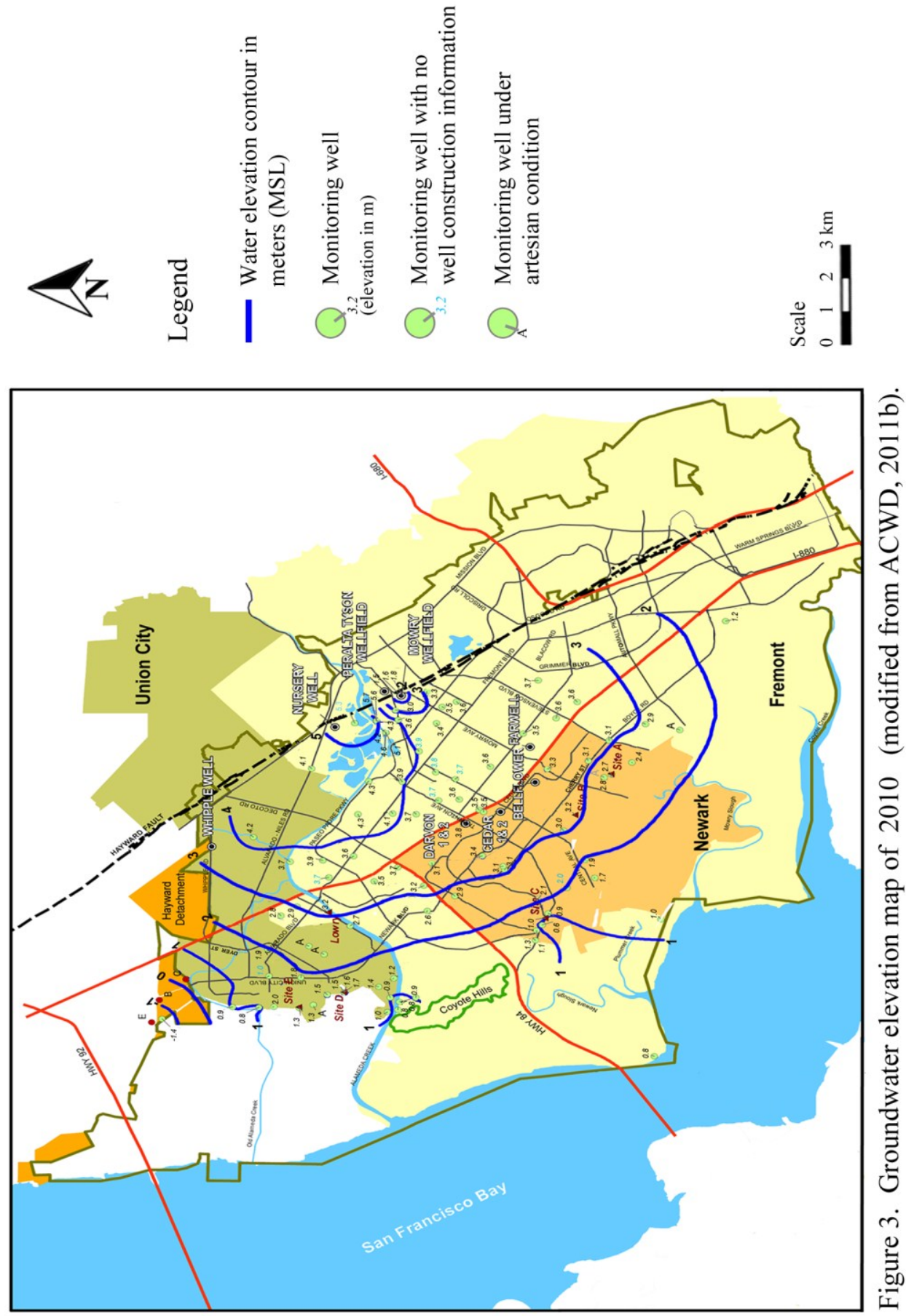


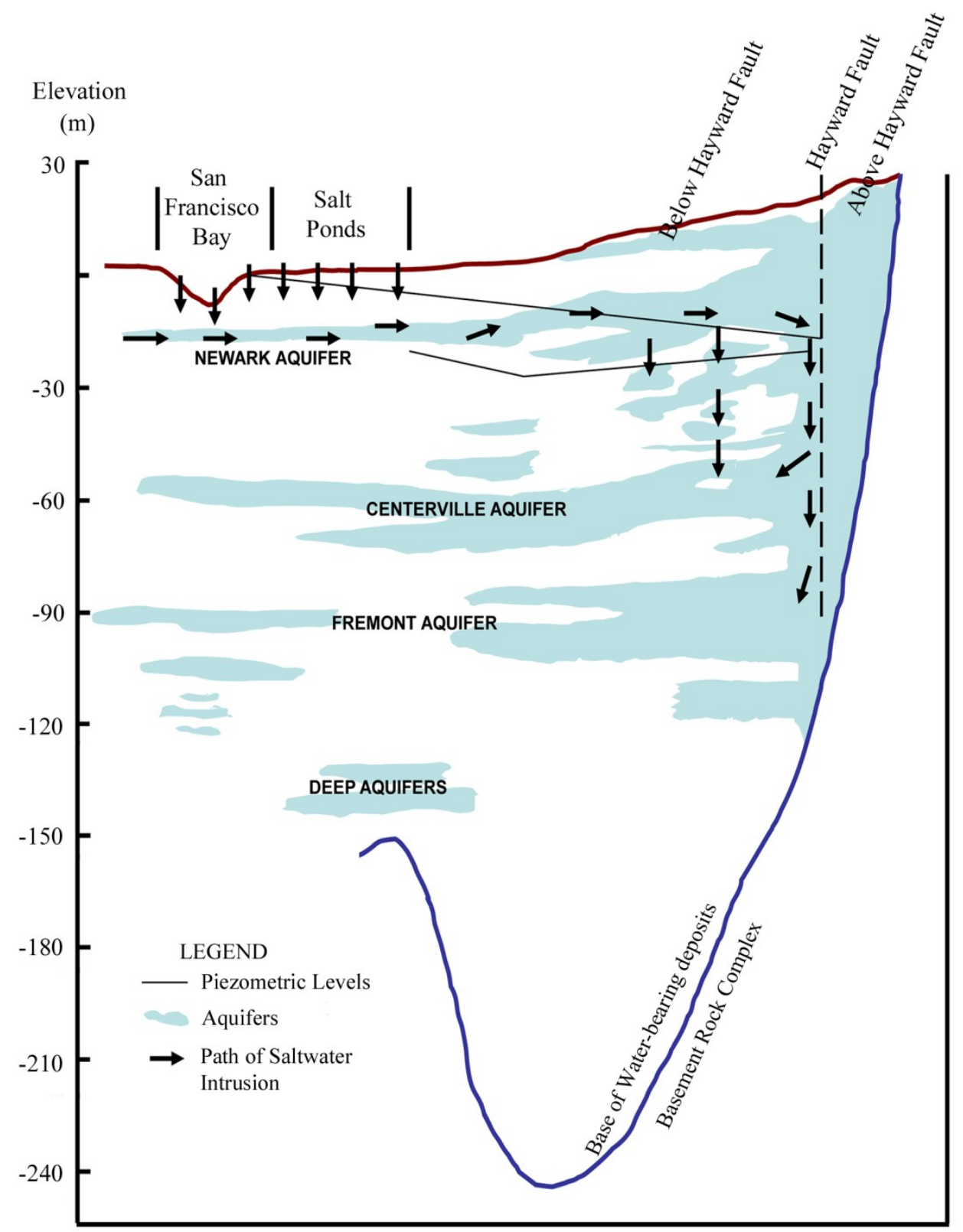

Figure 4. Diagram of saltwater intrusion (modified from ACWD, 2010a). 
sub-basin was not affected by the saltwater contamination because of the barrier effect created by the Hayward fault, hence it maintained its quality.

In 1962, the combined water management programs of ACWD resulted in the improvement of groundwater quality, although a considerable amount of saltcontaminated groundwater still remains in the aquifers. The improved water quality was evidenced by the chloride content of the groundwater monitored by ACWD. In one monitoring well, 4S1W-30E4, the chloride content in the Newark aquifer decreased from a high of 2,200 ppm in 1985 to $200 \mathrm{ppm}$ in 2010. Likewise, the chloride content of the Centerville-Fremont aquifers decreased from a high chloride content of 1,600 ppm in 1976 to $250 \mathrm{ppm}$ in 2010, in monitoring well 4S1W-14N3 (ACWD, 2010a). The maximum allowable concentration recommended by the U.S. Environmental Protection Agency for chloride in drinking water is $250 \mathrm{mg} / \mathrm{L}$ (USEPA, 2009).

\section{ACWD Groundwater Use}

ACWD obtains its imported surface water from the State Water Project's South Bay Aqueduct, Hetch Hetchy Aqueduct, and Alameda Creek Watershed Runoff (Figure 5). The water from the State Water Project is mostly used to recharge the groundwater through percolation facilities, and a portion of the water received from the aqueduct is used to provide water directly to consumers after being purified in treatment plants. The water from the Hetch Hetchy Aqueduct is blended with water from other supply sources before being delivered to consumers. The runoff from Alameda Creek is used solely to 


recharge aquifers in the Niles Cone Groundwater Basin. The runoff water is stored behind inflatable rubber dams located along a stretch of Alameda Creek and then diverted to the infiltration ponds (Quarry Lakes Recreational Park). The water infiltrates from both the dammed stream bed and the lakes to recharge the underlying aquifers (ACWD, 2011a).

In addition, in 1973, ACWD implemented the Aquifer Reclamation Program (ARP) to assist in the removal of the trapped brackish water in the aquifers by pumping it from wells and discharging it to San Francisco Bay. Since 2003, when the Newark Desalination Facility (NDF) became operational, the water that is pumped out from the saltwater-affected portions of the aquifers has been treated and used for domestic water supply instead of being released into the Bay. The NDF uses reverse-osmosis technology to treat the brackish water before it is blended with water from other sources and released into the distribution system.

In 2009-2010, ACWD supplied water to about 330,000 people in its service area with an average consumption of 160,000 cubic meters per day $\left(\mathrm{m}^{3} / \mathrm{d}\right)$. Total groundwater production contributed $55,400 \mathrm{~m}^{3} / \mathrm{d}$ or $35 \%$ of the total daily water consumption with the balance coming from imported surface water. BHF aquifer production accounts for $32,100 \mathrm{~m}^{3} / \mathrm{d}$ or $20 \%$ of the total water consumption (ACWD, 2011b). ACWD is expected to increase the total groundwater output (including AHF) to $41 \%$ of consumption in 2012 (ACWD, 2012). 


\section{METHODS OF INVESTIGATION}

The ACWD's borehole database was utilized to achieve the objectives of this study. The inputs were mainly based on the geologic logs previously interpreted by ACWD, and no borehole geologic materials were examined in this study. The first step was to identify the boreholes that would be used in the study. Two hundred eighty geologic borehole logs stored in the database were reviewed and analyzed. After the logs

were reviewed, it was found that not all wells could be integrated into the study. Some of the boreholes were drilled in cluster locations. Cluster-located wells are two or more wells drilled close to each other to obtain subsurface hydrogeologic data at various depths. To avoid repetition of data in this study, boreholes drilled in a cluster location were represented with only one well $\log$. There are about 50 cluster well locations in the database. All of the wells in the database that were located in the AHF sub-basin were omitted, because the study covered only the BHF area. Boreholes with a discrepancy in geographic coordinates were likewise excluded, although some whose coordinates were subsequently corrected by ACWD were then included in the investigation. Although there are gaps in the southeast portion predominantly underlain by clay, the study area is adequately covered with borehole data. The study used data from 110 borehole logs, and the locations of the boreholes are shown in Figure 6.

The second step was to interpret the observed lithologic description of the selected boreholes as hydrostratigraphic units. The observed lithology is simply the 


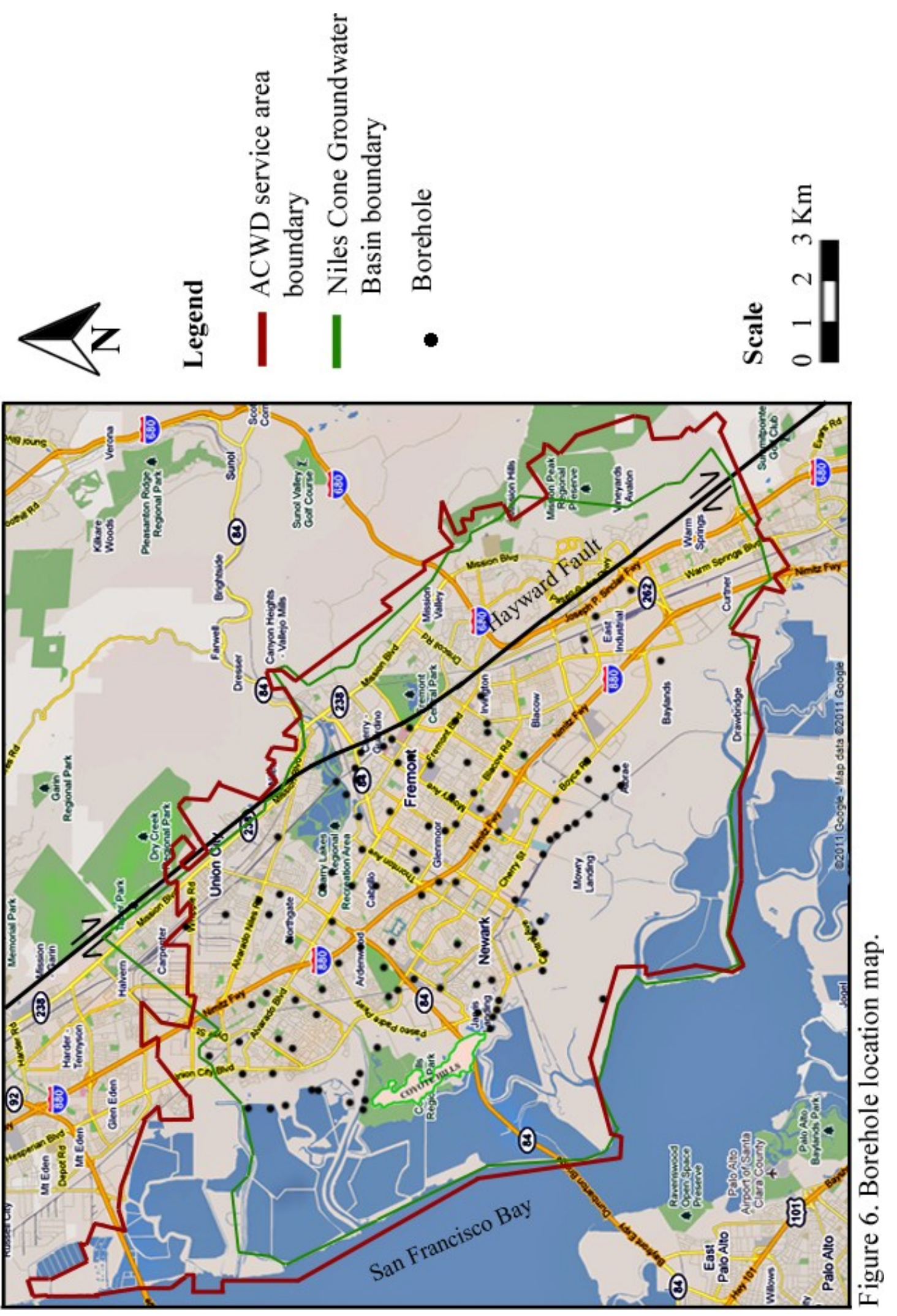


downhole sediment description such as sand, clay, or sand and clay, whereas the interpreted hydrostratigraphy is a group of lithologies with similar hydraulic characteristics. Based on similarity of hydraulic characteristics, the group of lithologies can be classified into aquifers and aquitards. A vertical sequence of coarse-grained lithologies (i.e., sand and gravel) can be classified as one stratigraphic unit, an aquifer, and, in the same manner, the clay and silt can be grouped together as one stratigraphic unit, an aquitard. The interlayered character of the aquifer (coarse-grained) and aquitard (fine-grained) units in the basin indicates glacial and interglacial stages of the recent past, which correspond to the fluctuation of the discharge and load capacity of Alameda Creek (Koltermann and Gorelick, 1992).

For purposes of this study, only the Newark Aquifer and deposits overlying it were interpreted and grouped into correlatable hydrostratigraphic units with corresponding depth intervals. In this investigation, any uppermost deposits that were silty and clayey were referred to as the Upper Aquitard, and any sandy or gravelly deposits within the upper $15 \mathrm{~m}$ of the basin were called the Shallow Aquifer. The clayey and silty deposit separating the Shallow and Newark aquifers is the Newark Aquitard. In areas where the Shallow Aquifer is missing and only the Newark Aquitard overlies the Newark Aquifer, the uppermost 2-m layer was arbitrarily designated as Upper Aquitard. This value is the minimum thickness observed where the fine-grained material overlies the Shallow Aquifer deposits. 
Below are examples of the different hydrostratigraphic interpretations that were adopted in this study based on the lithologic log descriptions in the database. Table 2 presents a typical interpretation where the sand and gravel formation, Shallow Aquifer, occurs between the uppermost clay layer, the Upper Aquitard, and an underlying clay bed, the Newark Aquitard

TABLE 2. HYDROSTRATIGRAPHIC INTERPRETATION FOR TYPICAL SHALLOW AQUIFER CASE

\begin{tabular}{|c|c|c|c|c|c|}
\hline \multicolumn{3}{|c|}{ Lithology } & \multicolumn{3}{|c|}{ Hydrostratigraphy } \\
\hline \multicolumn{2}{|c|}{$\begin{array}{c}\text { Depth } \\
\text { (m) }\end{array}$} & \multirow[t]{2}{*}{ Description } & \multicolumn{2}{|c|}{$\begin{array}{l}\text { Depth } \\
\text { (m) }\end{array}$} & Description \\
\hline From & To & & From & To & \\
\hline 0.0 & 2.0 & Overburden & & & \\
\hline 2.0 & 3.6 & Clay & & & \\
\hline 3.6 & 6.4 & Clay & 0.0 & 6.4 & Upper Aquitard \\
\hline 6.4 & 8.0 & Sand & & & \\
\hline 8.0 & 10.0 & Gravel & 6.4 & 10.0 & Shallow Aquifer \\
\hline 10.0 & 12.1 & Clay & 10.0 & 12.1 & Newark Aquitard \\
\hline 12.1 & 12.8 & Sand & & & \\
\hline 12.8 & 21.0 & Gravel & 12.1 & 21.0 & Newark Aquifer \\
\hline
\end{tabular}

Note: Borehole 4S2W-24L3. 
Table 3 illustrates the case where the gravelly layer, the Shallow Aquifer, is exposed on the surface while being underlain by a clay bed, the Newark Aquitard, and sand and gravel layers, the Newark Aquifer.

TABLE 3. HYDROSTRATIGRAPHIC INTERPRETATION FOR EXPOSED

SHALLOW AQUIFER CASE

\begin{tabular}{|c|c|c|c|c|c|}
\hline \multicolumn{3}{|c|}{ Lithology } & \multicolumn{3}{|c|}{ Hydrostratigraphy } \\
\hline \multicolumn{2}{|c|}{$\begin{array}{c}\text { Depth } \\
\text { (m) }\end{array}$} & \multirow[t]{2}{*}{ Description } & \multicolumn{2}{|c|}{$\begin{array}{l}\text { Depth } \\
\text { (m) }\end{array}$} & \multirow[t]{2}{*}{ Description } \\
\hline From & To & & From & To & \\
\hline 0.0 & 3.0 & Gravel & 0.0 & 3.0 & Shallow Aquifer \\
\hline 3.0 & 22.0 & Clay & 3.0 & 22.0 & Newark Aquitard \\
\hline 22.0 & 45.0 & Sand & 22.0 & 45.0 & \\
\hline 45.0 & 52.0 & Gravel & 45.0 & 52.0 & Newark Aquifer \\
\hline
\end{tabular}

Note: Borehole 4S2W-12K8.

Table 4 illustrates an additional hydrostratigraphic interpretation where the Upper Aquitard is missing and the Shallow Aquifer overlies the Newark Aquifer. The thin layer $(0.6 \mathrm{~m})$ of silt was considered part of the Shallow Aquifer deposit in the uppermost $2 \mathrm{~m}$. The borehole is located at the Forebay area. 
TABLE 4. HYDROSTRATIGRAPHIC INTERPRETATION FOR ALL COARSE-

GRAINED MATERIAL CASE

\begin{tabular}{|c|c|c|c|c|c|}
\hline \multicolumn{3}{|c|}{ Lithology } & \multicolumn{3}{|c|}{ Hydrostratigraphy } \\
\hline \multicolumn{2}{|c|}{$\begin{array}{c}\text { Depth } \\
\text { (m) }\end{array}$} & \multirow[t]{2}{*}{ Description } & \multicolumn{2}{|c|}{$\begin{array}{l}\text { Depth } \\
\text { (m) }\end{array}$} & Description \\
\hline From & To & & From & To & \\
\hline 0.0 & 0.6 & Silt & & & \\
\hline 0.6 & 5.0 & Gravel & 0.0 & 2.0 & Shallow Aquifer \\
\hline 5.0 & 5.5 & Sand & & & \\
\hline 5.5 & 8.0 & Gravel & & & \\
\hline 8.0 & 9.7 & Sand & & & \\
\hline 9.7 & 17.7 & Gravel & & & \\
\hline 17.7 & 24.3 & Sand & 2.0 & 23.4 & Newark Aquifer \\
\hline
\end{tabular}

Note: Borehole 4S1W-20J5.

The third step in the project was to input the interpreted hydrostratigraphic classifications into the Rockworks $2002^{\circledR}$ software package along with the corresponding geographic coordinates. The software uses the borehole geologic data in subsurface visualizations such as contour maps and cross sections.

The outputs of Rockworks $2002^{\circledR}$ that were used in this study include the following:

1. Five stratigraphic cross-sections. The locations of the five lines of stratigraphic cross-section are shown in Figure 7. Two section lines are oriented in a northwesterly direction roughly parallel to the Hayward fault, one near the base 

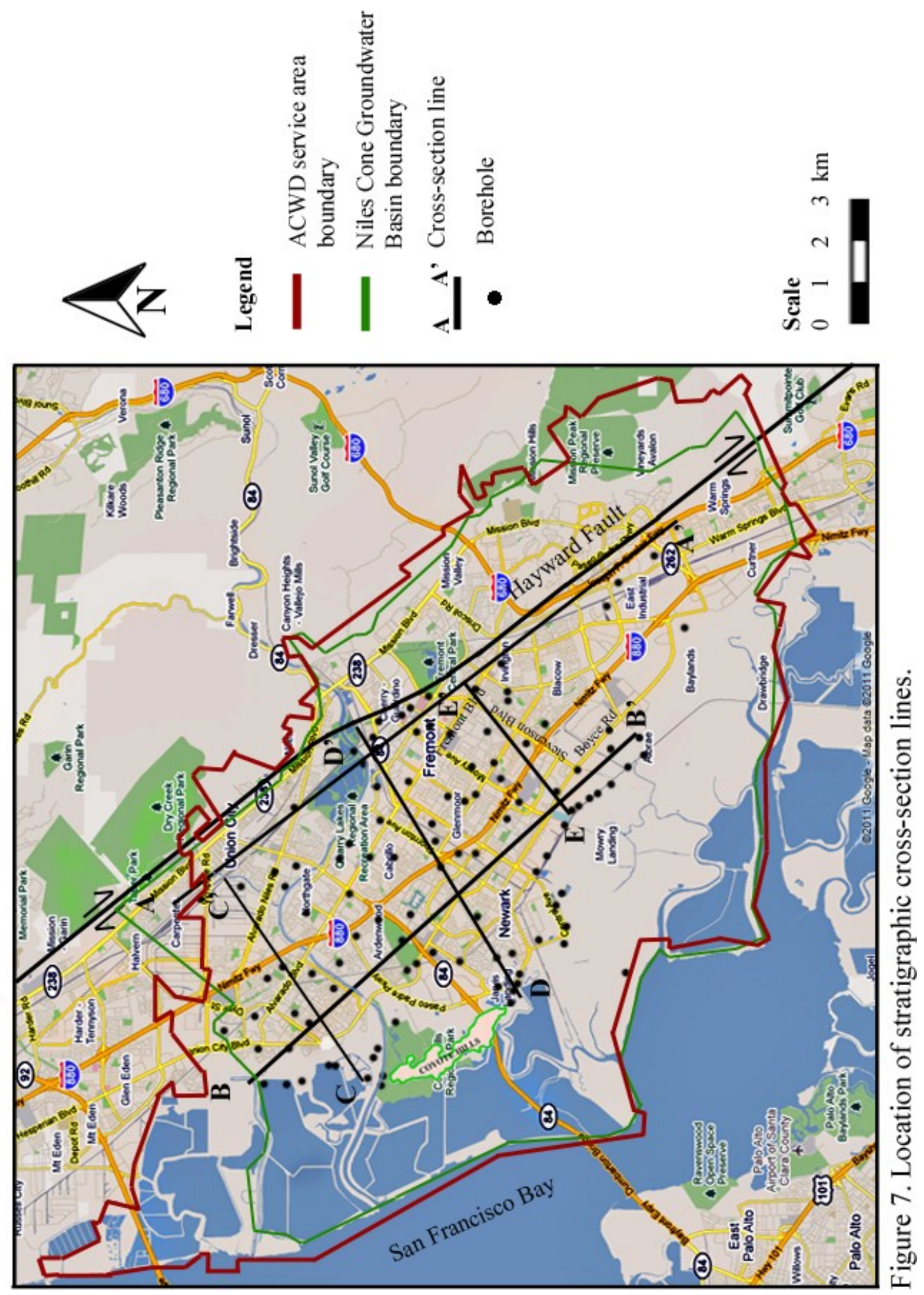
of the Diablo Range and one near the shoreline of San Francisco Bay. Three lines of section are oriented in a northeasterly direction.

2. Three thickness maps representing the Upper Aquitard, Shallow Aquifer, and Newark Aquitard. The thickness map is a 2-dimensional color flood showing the areal distribution of the varying thickness of the stratigraphic unit over the study area.

3. Three stratigraphic surface maps of the Shallow Aquifer, Newark Aquitard, and Newark Aquifer. The stratigraphic surface map is a two-dimensional color flood showing the top surface elevations of a selected stratigraphic unit.

4. A map showing where the Upper Aquitard overlying the Shallow Aquifer is absent or thin. Thin is defined as $2 \mathrm{~m}$ or less in thickness.

5. A map showing where the Newark Aquitard is thin or absent. Thin is defined as a thickness of $2 \mathrm{~m}$ or less.

6. A map showing which regions in ACWD's service area are most sensitive to contamination.

7. A map tracing the inferred paleodrainage courses that flowed within the Niles Cone Groundwater Basin based on a Shallow Aquifer thickness of $1 \mathrm{~m}$ or more.

The fourth step was to review the visualization results. After the initial plots were generated, they were analyzed for validity and reasonableness based on knowledge of geologic conditions in the area. Analysis tools in Rockworks $2002^{\circledR}$ were used in the adjustments and refining of the generated visualizations. Some gridding methods in Rockworks $2002^{\circledR}$ were likewise tried in interpolating the data. The inverse-distance 
gridding method was deemed to reflect most accurately the general geologic conditions in the study area.

The fifth step was the geologic interpretation of the lateral extent of the Shallow Aquifer, based on the visualizations described above. 


\section{RESULTS}

With all of the visualizations presented in this section, two things must be kept in mind. First, the data density of the boreholes is in some places on the order of kilometers, whereas some features, such as stream channels, have dimensions on the order of meters or tens of meters. Thus the data density may not be high enough to identify all smaller features. Secondly, Rockworks $2002^{\circledR}$ uses consistent interpolation algorithms between data points that may create features, such as "bull's eyes" on contour maps, that are contouring artifacts rather than reflections of a geologic reality. Another software artifact results in an inaccurate thickness in some of the stratigraphic units in cross sections. A contour interval of $0.5 \mathrm{~m}$ was used in the maps to clearly display the thickness variability and elevation of the stratigraphic unit.

\section{Thickness Maps}

Except at the Forebay and the northern portion of the study area, the Upper Aquitard covers almost the entire Niles Cone Groundwater Basin. Figure 8 presents the thickness map of the Upper Aquitard. The absence of the Upper Aquitard in the Forebay indicates that the fine grained aquitard materials were washed away by the continuous flow of the Alameda Creek as it drained westward. Left behind were the heavier and coarser materials near the fan apex. The missing Upper Aquitard in the Forebay stretches $3 \mathrm{~km}$ westward from the Hayward fault. Likewise, its absence in the northern part of the 

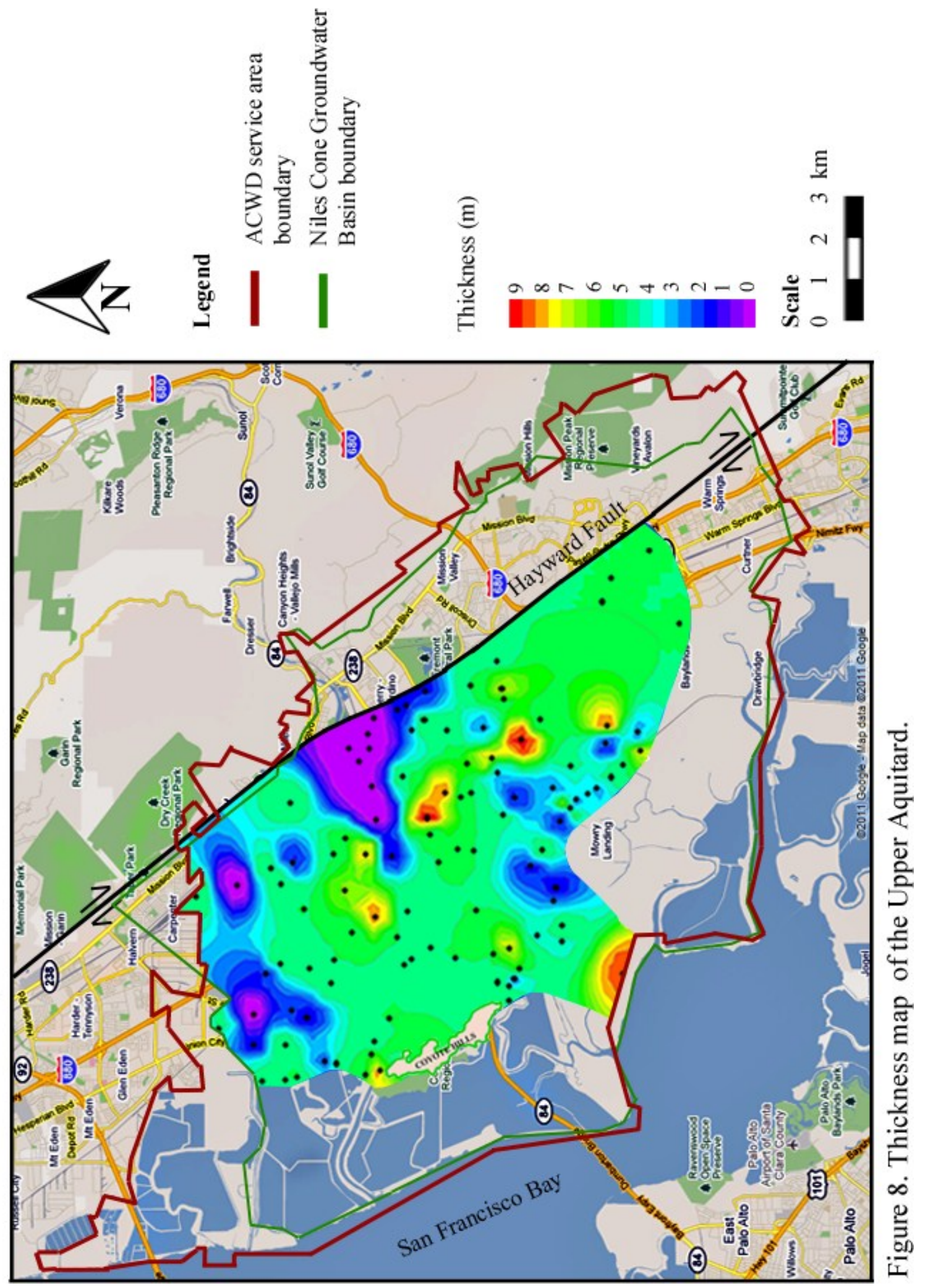
study area suggests the presence of another paleodrainage channel, probably from the smaller Dry Creek alluvial fan.

The thickness map of the Shallow Aquifer in Figure 9 indicates that it was not deposited throughout the Niles Cone Groundwater Basin. It is mostly found in the Forebay and in some localized areas, in total covering approximately $40 \%$ of the study area. Apparently, its abundance around the Forebay area may indicate continuous deposition of coarse-grained materials by the creek. The presence of isolated shallow coarse-grained materials in other areas may also suggest that they are remnants of the paleochannel course of Alameda Creek as it flowed westward towards the Bay. The greater absence of the Shallow Aquifer east of the Coyote Hills implies that, during the Holocene Epoch, Alameda Creek did not flow near the hills but mainly flowed southwest of the hills and, perhaps at times, northwest towards San Francisco Bay.

In Figure 10, the Newark Aquitard is missing in the Forebay area where the aquifers are predominantly present from surface to considerable depth. The figure likewise shows isolated areas of thin ( $2 \mathrm{~m}$ thick or less) Newark Aquitard deposits, and a predominance of thick clay deposits in the southern and northeastern part of the study area. The thickness of the Newark Aquitard is important because thicker deposits hinder downward movement of shallow pollutants to the underlying, groundwater-producing Newark Aquifer. In areas where the aquitard is thinner ( $2 \mathrm{~m}$ or less), pollutants could migrate downward more easily. 


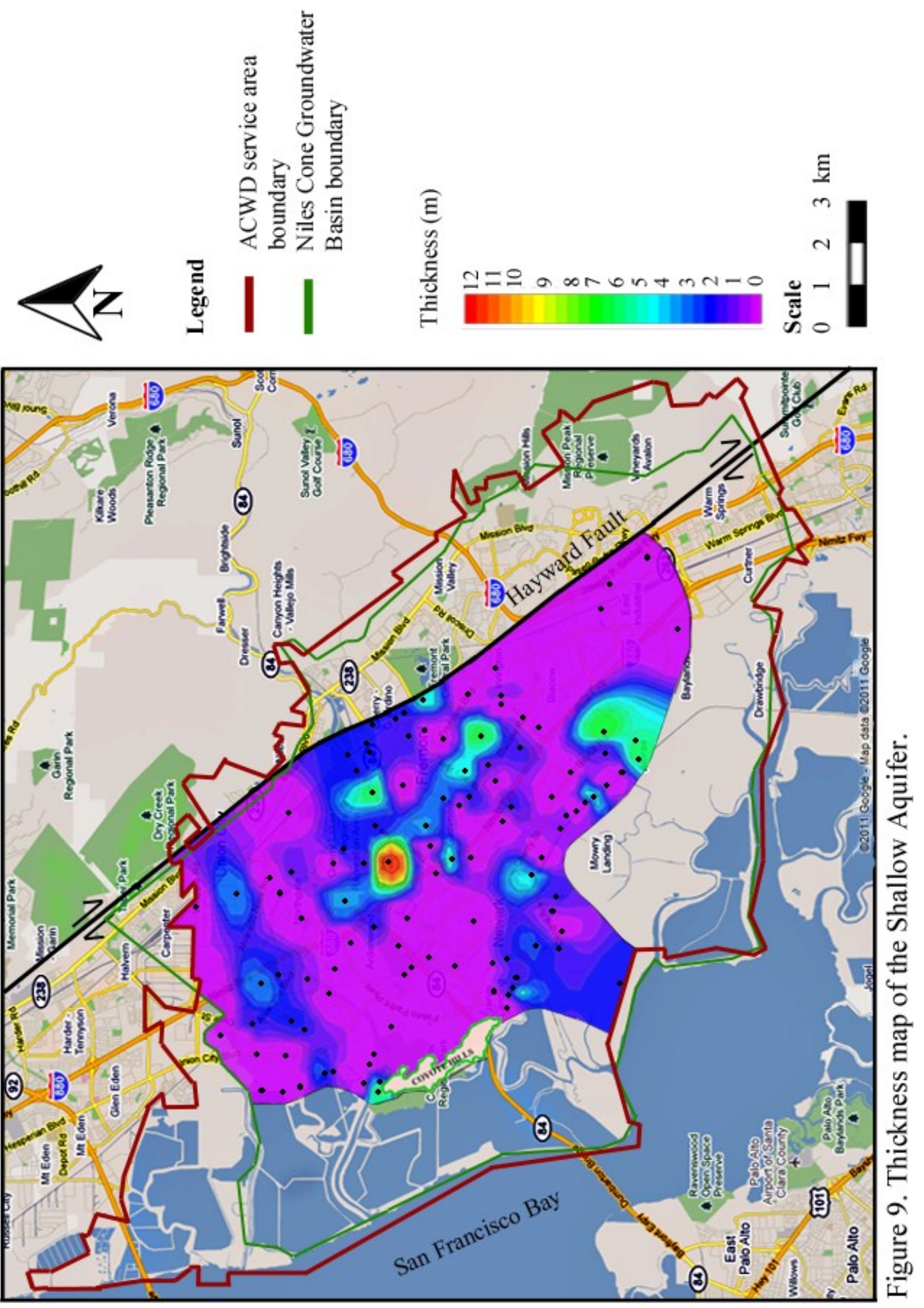



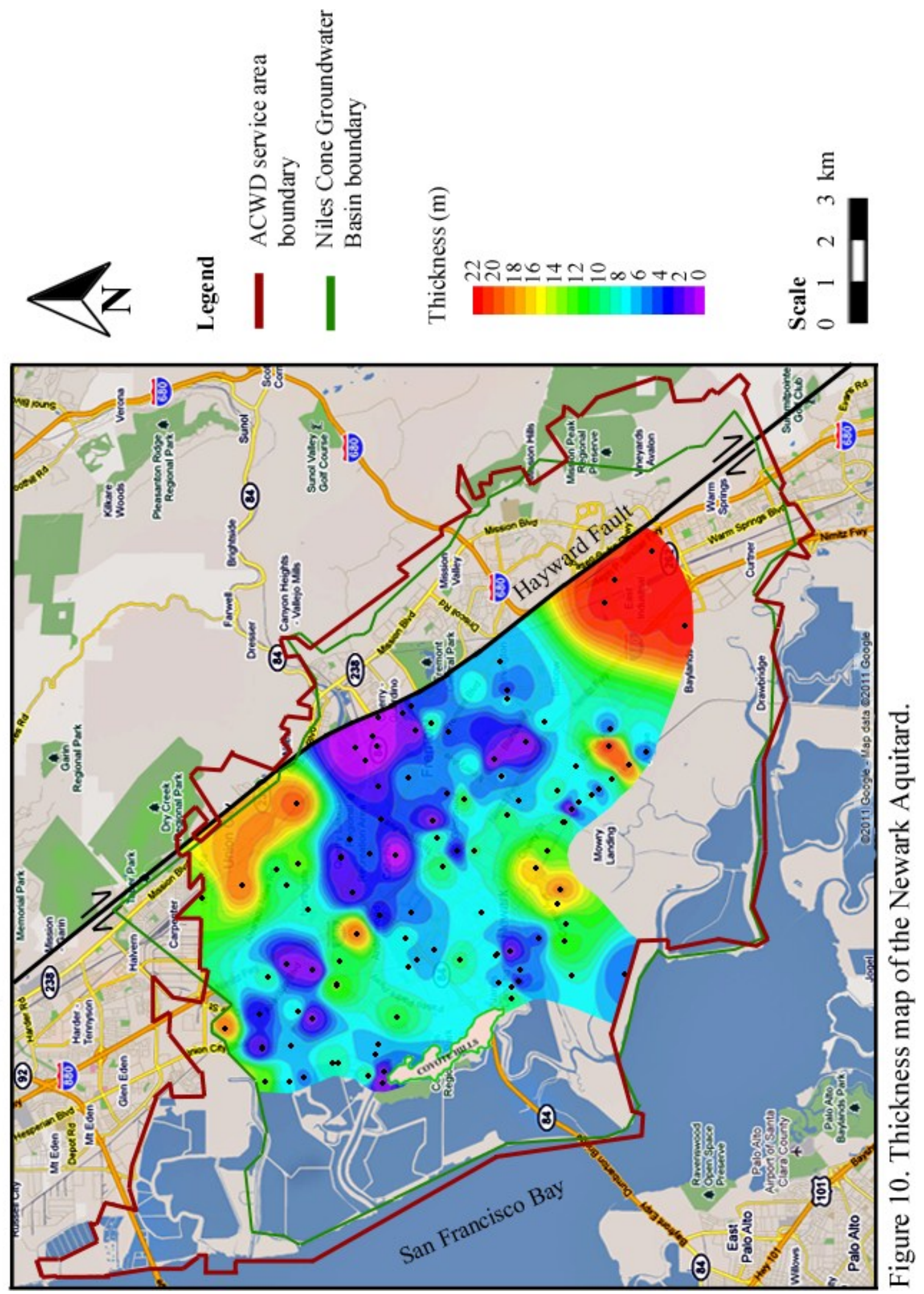


\section{Stratigraphic Surface Maps}

The Shallow Aquifer deposits in the Niles Cone basin primarily slope southwest toward the Bay, with the highest elevation of about $20 \mathrm{~m}$ above mean sea level (amsl) at the Forebay area and the lowest at $8 \mathrm{~m}$ below mean sea level (bmsl) in the west, as shown in Figure 11. An elevated Shallow Aquifer also exists in the north of the study area where it is inferred to be part of the apex of the smaller Dry Creek alluvial fan. If the aquifer is entirely alluvial, the elevation of the lowest Shallow Aquifer bottom, which was encountered at $12 \mathrm{~m} \mathrm{bmsl}$, indicates that part of the aquifer was deposited when San Francisco Bay was still at least $12 \mathrm{~m}$ below the present sea level. Several investigators conducted studies on eustatic sea-level rise. The study of Atwater et al. (1977) on Holocene sea level changes in southern San Francisco Bay showed that the Shallow Aquifer began to be deposited at the latest around 7,000 years before present (Figure 12) following the last glacial low stand. The deposition continued up to the present at least in the Forebay area.

Figure 13 shows that the Newark Aquitard also slopes southwesterly, with the highest elevation of its top at $20 \mathrm{~m}$ amsl in the south, where there are predominantly clayey deposits, and the lowest elevation of its upper surface at $12 \mathrm{~m}$ bmsl. The Newark Aquifer likewise dips southwesterly, with the highest elevation of its upper surface at $8 \mathrm{~m}$ amsl in the Forebay and the lowest point of its upper surface elevation at $30 \mathrm{~m} \mathrm{bmsl}$, in the south, as shown in Figure 14. 

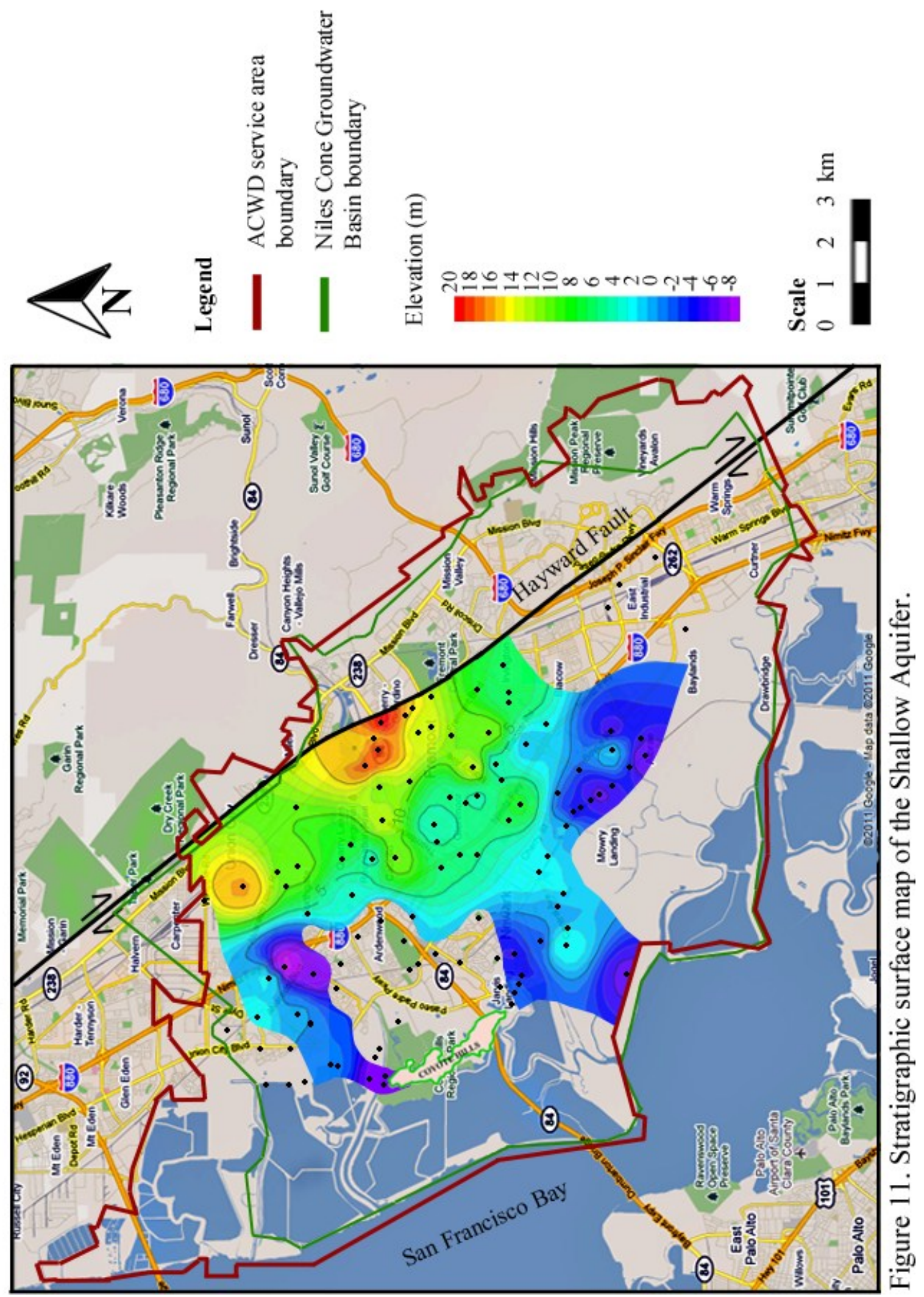


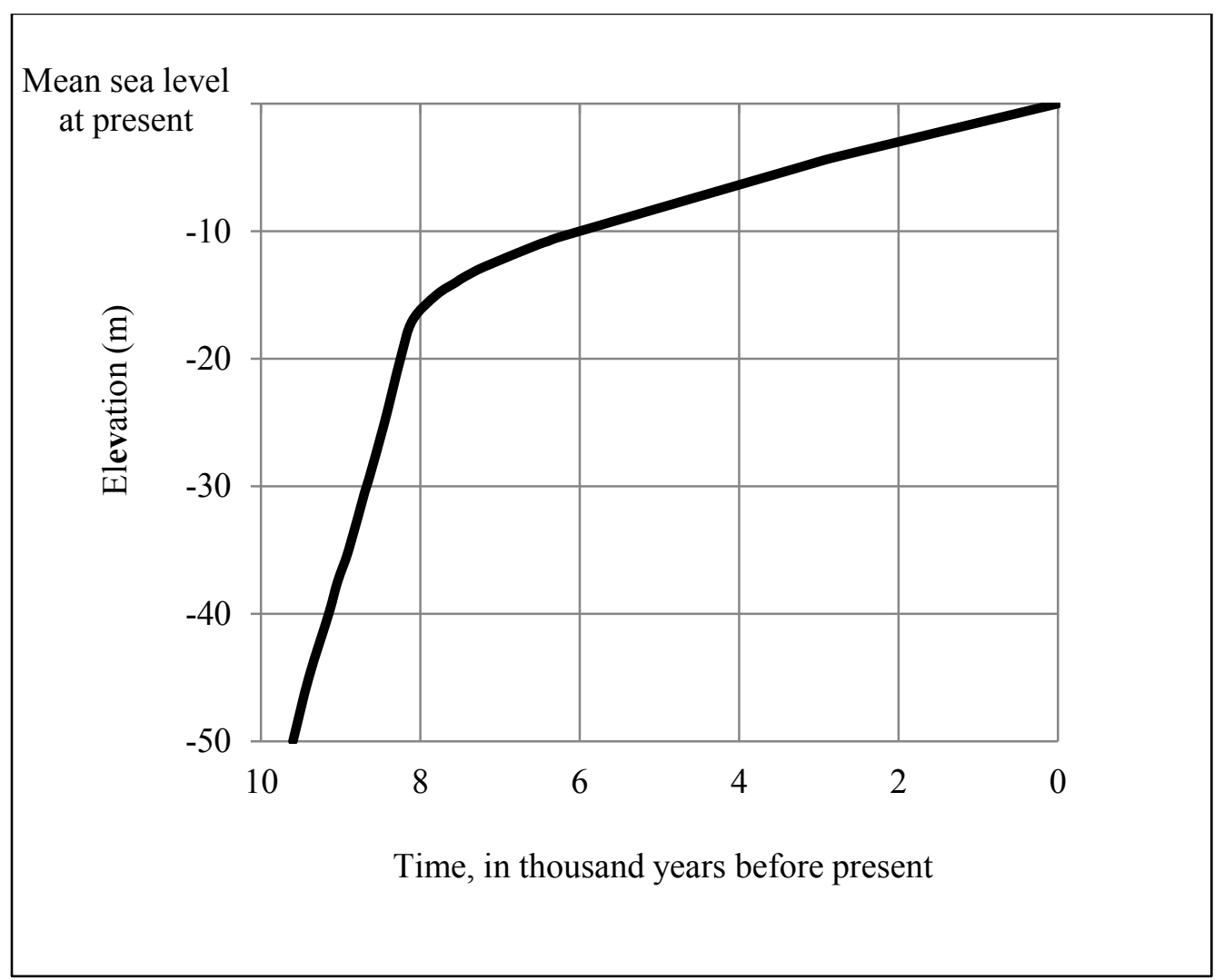

Figure 12. Sea-level changes in southern San Francisco Bay during Holocene Epoch (modified from Atwater et al., 1997). 


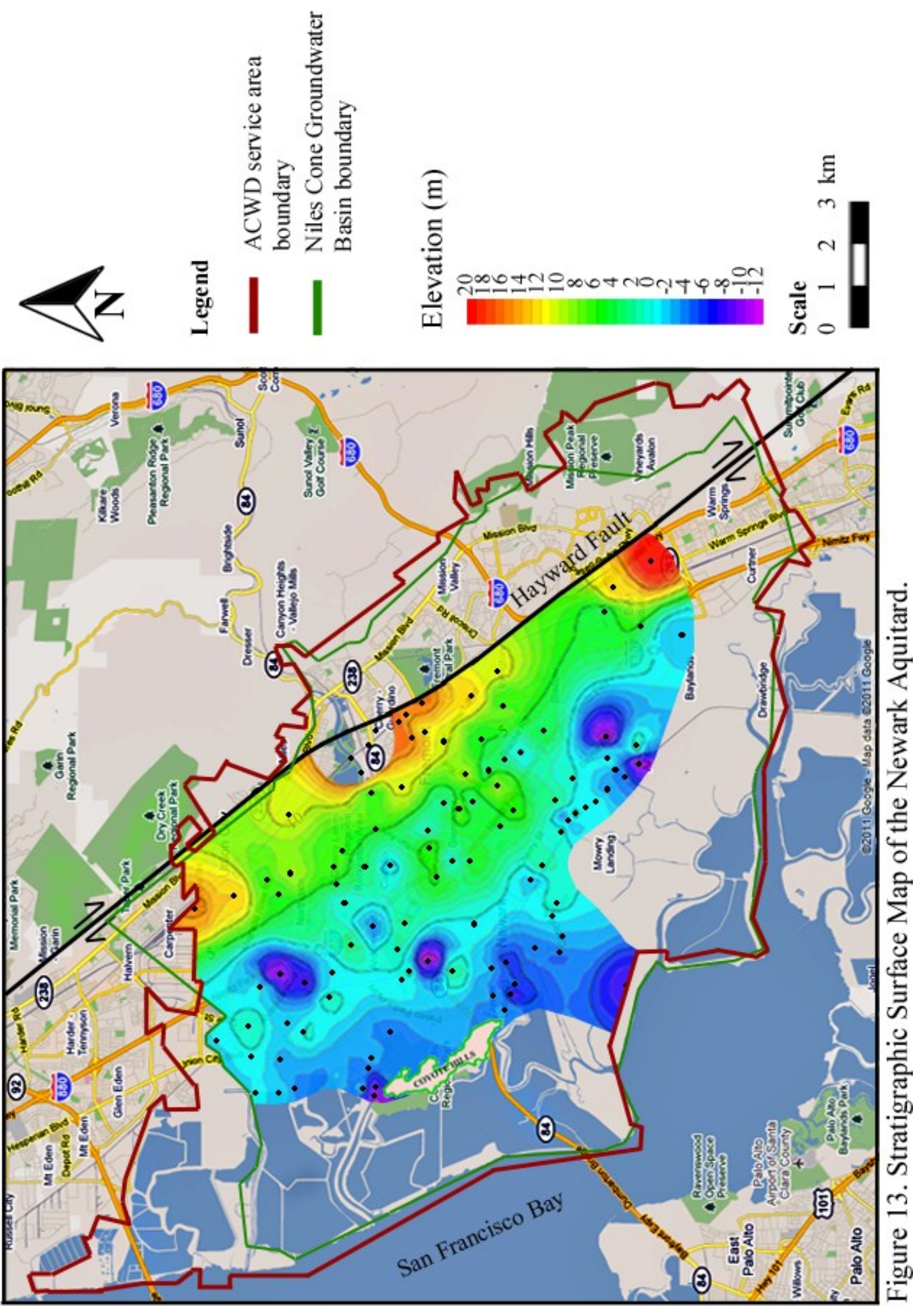




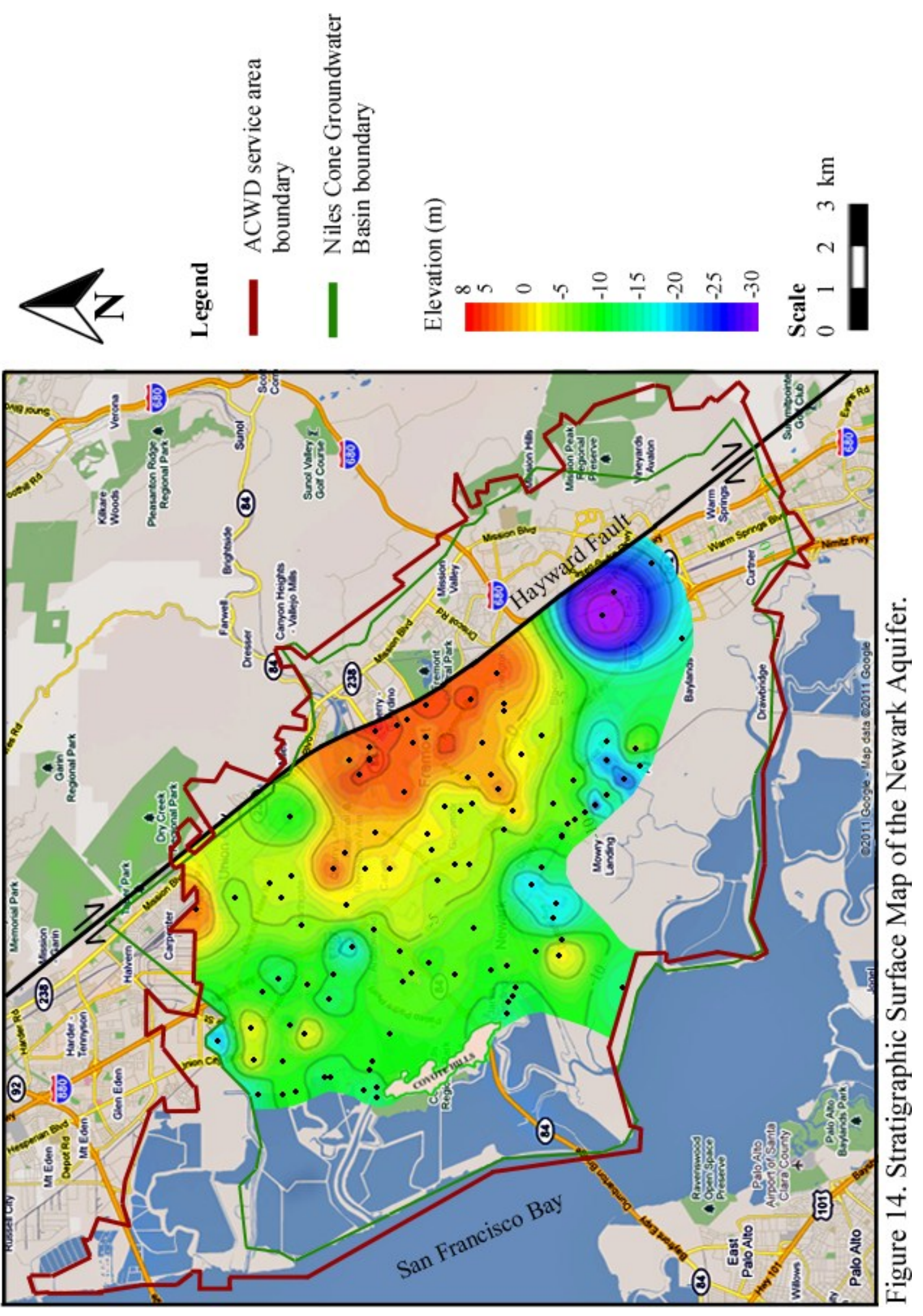




\section{Hydrostratigraphic Cross-sections}

In examining the cross-sections, it is useful to keep in mind that the vertical exaggeration is 100 -fold. Tick marks along the top edge of the sections indicate the location of the boreholes whose logs are the basis for the hydrostratigraphy. Figure 7 shows the locations of the cross-sections.

The hydrostratigraphic sections in Figures 15 through 19 generally illustrate that the Shallow Aquifer is not uniformly distributed throughout the Niles Cone Groundwater Basin. Cross-section A-A' (Figure 15), which is parallel to and near the Hayward fault, shows that the Shallow Aquifer is only present in the mid-section, the Forebay area near where Alameda Creek exits Niles Canyon, and in the north as part of the apex of the Dry Creek alluvial fan. Both aquifer deposits are exposed at the ground surface. The Shallow Aquifer is significantly absent in the southern part of the section and the Newark Aquifer occurs at greater depths.

Cross-section B-B' in Figure 16 runs parallel to section A-A', but is located near

the bayshore. It shows that the Shallow Aquifer is likewise discontinuous, localized, and thin. The section also indicates that the Shallow Aquifer was deposited at depths slightly above the present sea level at this location, but between thick aquitards. The section indicates the absence of hydraulic connection between the Shallow Aquifer and the underlying Newark Aquifer. 


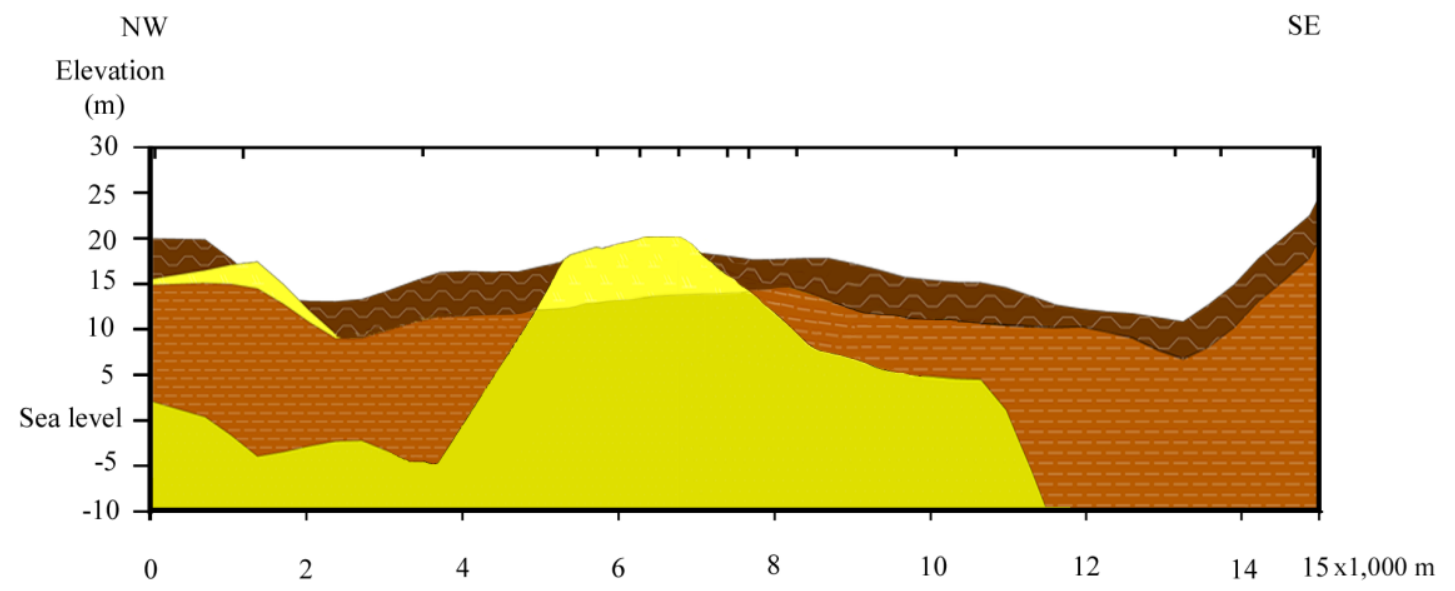

Figure 15. Hydrostratigraphic cross-section A-A'

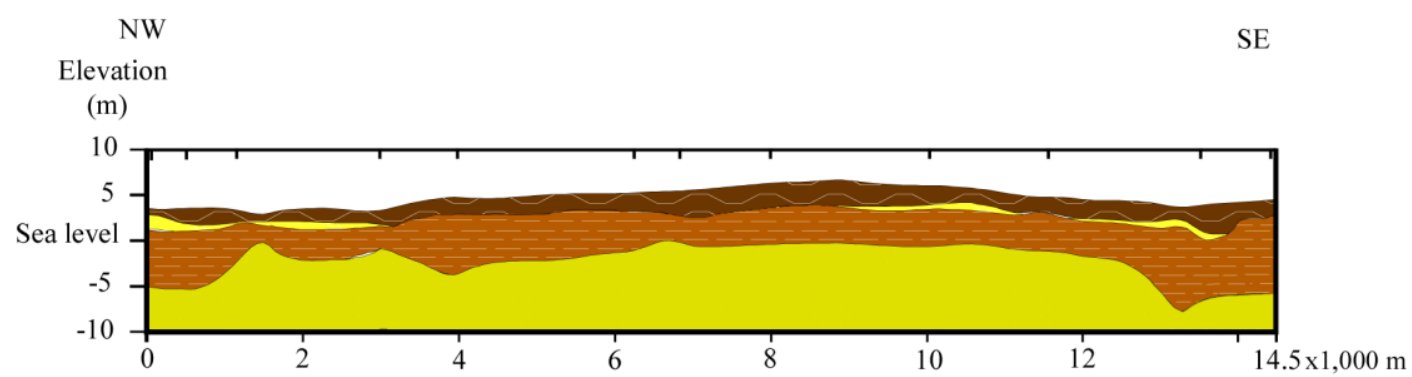

Figure 16. Hydrostratigraphic cross-section B-B'

Legend:

Upper Aquitard

Shallow Aquifer

Newark Aquitard

Newark Aquifer 


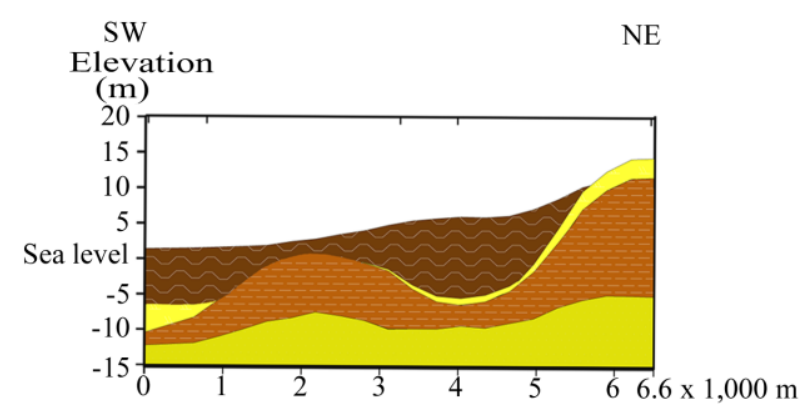

Figure 17. Hydrostratigraphic cross-section C-C'

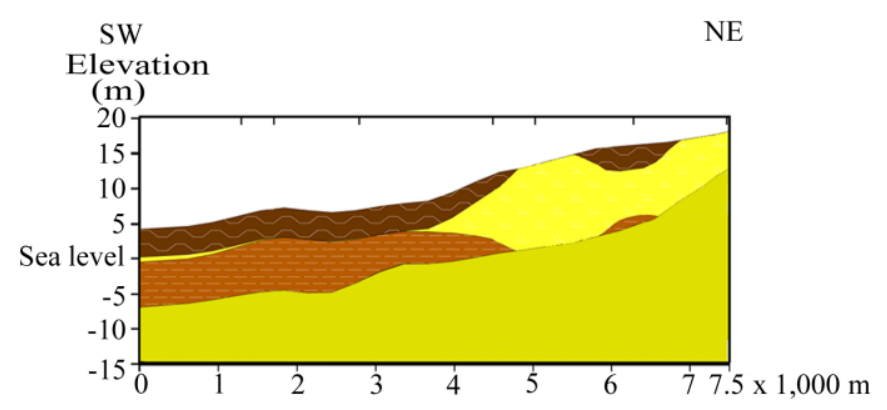

Figure 18. Hydrostratigraphic cross-section D-D'

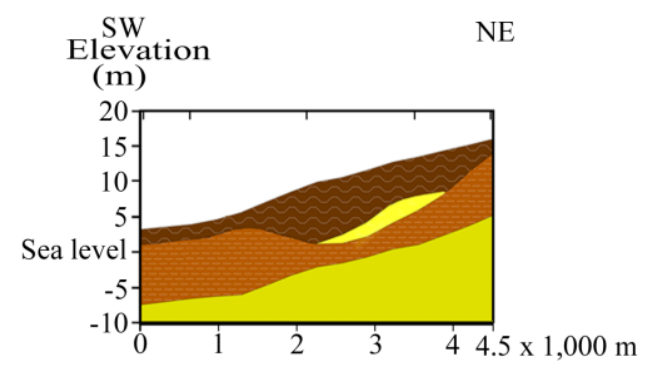

Figure 19. Hydrostratigraphic cross-section E-E'

Legend:

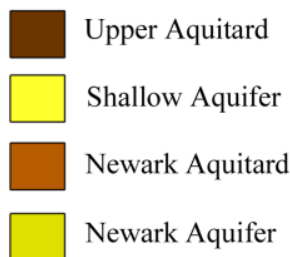


The hydrostratigraphic cross-section C-C' (Figure 17) in the northernmost part of the study area cuts the exposed Shallow Aquifer deposits of the smaller Dry Creek alluvial fan, which is underlain by the Newark Aquitard. The section also indicates a Shallow Aquifer deposit near the bayshore; it lies about $8 \mathrm{~m}$ below present sea level with a thin underlying aquitard of about $2 \mathrm{~m}$ thickness but with a thick Upper Aquitard above it. This indicates that in the western part of the northern section of the study area the thick aquitard shields the hydraulically connected Shallow Aquifer and Newark Aquifer from contamination.

Cross-section D-D' in Figure 18 extends from the Coyote Hills towards the Forebay area. It significantly shows missing Upper and Newark Aquitards in the Forebay area, hence exposing the Shallow Aquifer deposit at the ground surface. The section also displays the hydraulic connectivity of the Shallow Aquifer with the underlying Newark Aquifer, thus indicating vulnerability of the Forebay area to surface contamination. Although an isolated Shallow Aquifer deposit is present in the southwestern end of the section near the shoreline, it is thickly overlain and underlain by aquitards, thus downward movement of potential contaminants to the underlying aquifer would be greatly impeded.

Cutting across the study area, approximately along Stevenson Blvd. from Boyce Road to Fremont Blvd. in the city of Fremont (Figure 7), is cross-section E-E' (Figure 19). It primarily shows thick aquitard deposits with a localized, confined Shallow Aquifer. This section further indicates that the Shallow Aquifer is a discontinuous deposit. 


\section{DISCUSSION}

The figures presented in the previous section can be interpreted to answer questions about the sensitivity of the aquifers to contamination and about the depositional history of the Shallow Aquifer. The data set used for this study did not include the many wells installed at environmental cleanup sites. If those wells or non-geologic factors (e.g., abandoned wells, man-made structures, etc.) had been included, it is possible that other areas sensitive to contamination would have been identified. It is also possible that such areas exist where no investigation has taken place.

\section{Sensitivity to Contamination}

A map (Figure 20) was drawn delineating where the Upper Aquitard deposits are thin (thickness $2 \mathrm{~m}$ or less) or absent to show areas in the Niles Cone Groundwater Basin where the Shallow Aquifer is sensitive to potential surface contamination. The map indicates that the Upper Aquitard is mainly missing in the Forebay and in the northernmost part, with thin Upper Aquitard deposits scattered across the rest of the study area. The region where the Shallow Aquifer is most sensitive to impact encompasses nearly $15 \%$ of the study area. However, contaminants from leaking pipelines and underground storage tanks could never be disregarded because they could move downwards even in areas where the Upper Aquitard is more than $2 \mathrm{~m}$ thick. 


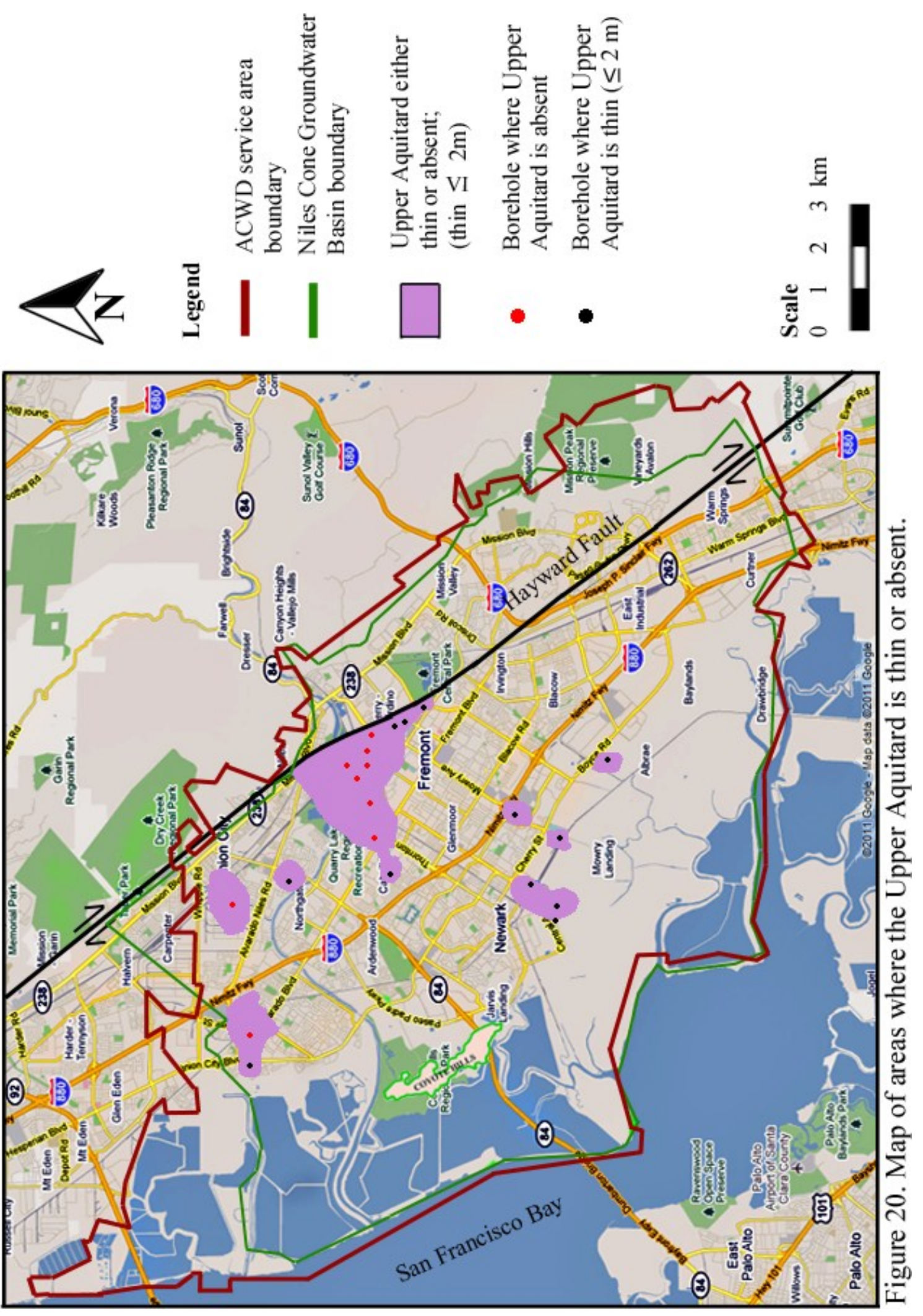


To show hydraulic connection between the Shallow Aquifer and the underlying Newark Aquifer, the thickness of the intervening Newark Aquitard was delineated to show where the deposits are thin or absent (as illustrated in Figure 21). It shows that the Newark Aquitard is missing in the Forebay with some thin deposits irregularly distributed elsewhere in the study area. The map also indicates the locations of the potential migration pathways to the underlying Newark Aquifer if contamination occurs in the Shallow Aquifer. The region of enhanced hydraulic connectivity between the aquifers covers approximately $15 \%$ of the study area.

Figure 22 shows the area where both the Upper Aquitard and Newark Aquitard are thin ( $2 \mathrm{~m}$ or less) or absent illustrating the location in the study area that is most sensitive to surface contamination in the Niles Cone Groundwater Basin. Likewise, it identifies areas where the potential downward movement of surface contaminants to the first drinking-water aquifer would be most likely. These highly sensitive regions are localized near to some of the ACWD's production wells, indicating a potential hazard.

\section{Recent Depositional History}

To provide additional information on the development of the Niles Cone Groundwater Basin, the paleodrainage channels present during the Holocene Epoch were inferred by tracing the deposits of the shallow, coarse-grained sediments with a thickness of $1 \mathrm{~m}$ or greater. In Figure 23, the map of the inferred paleodrainage channels shows 


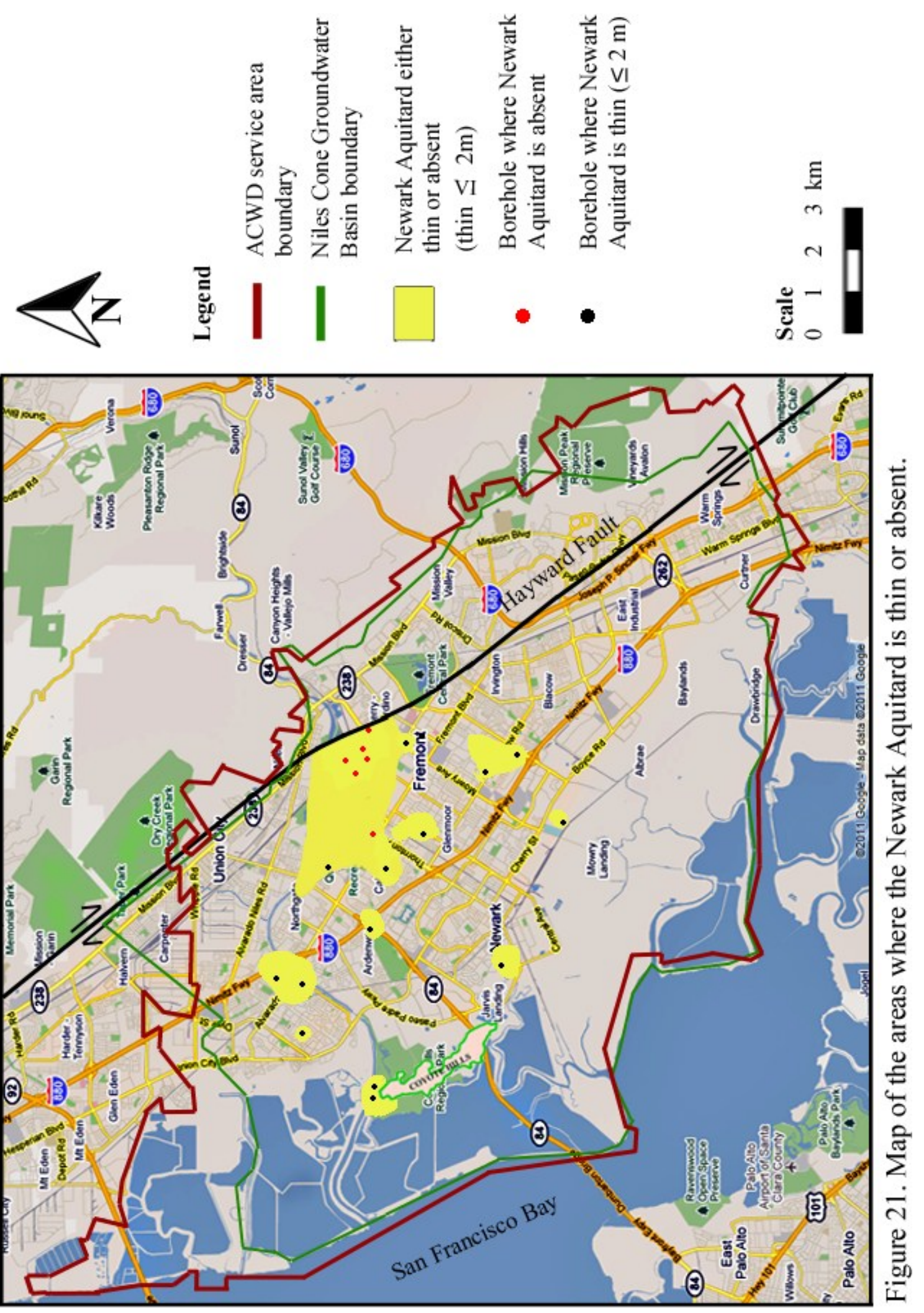




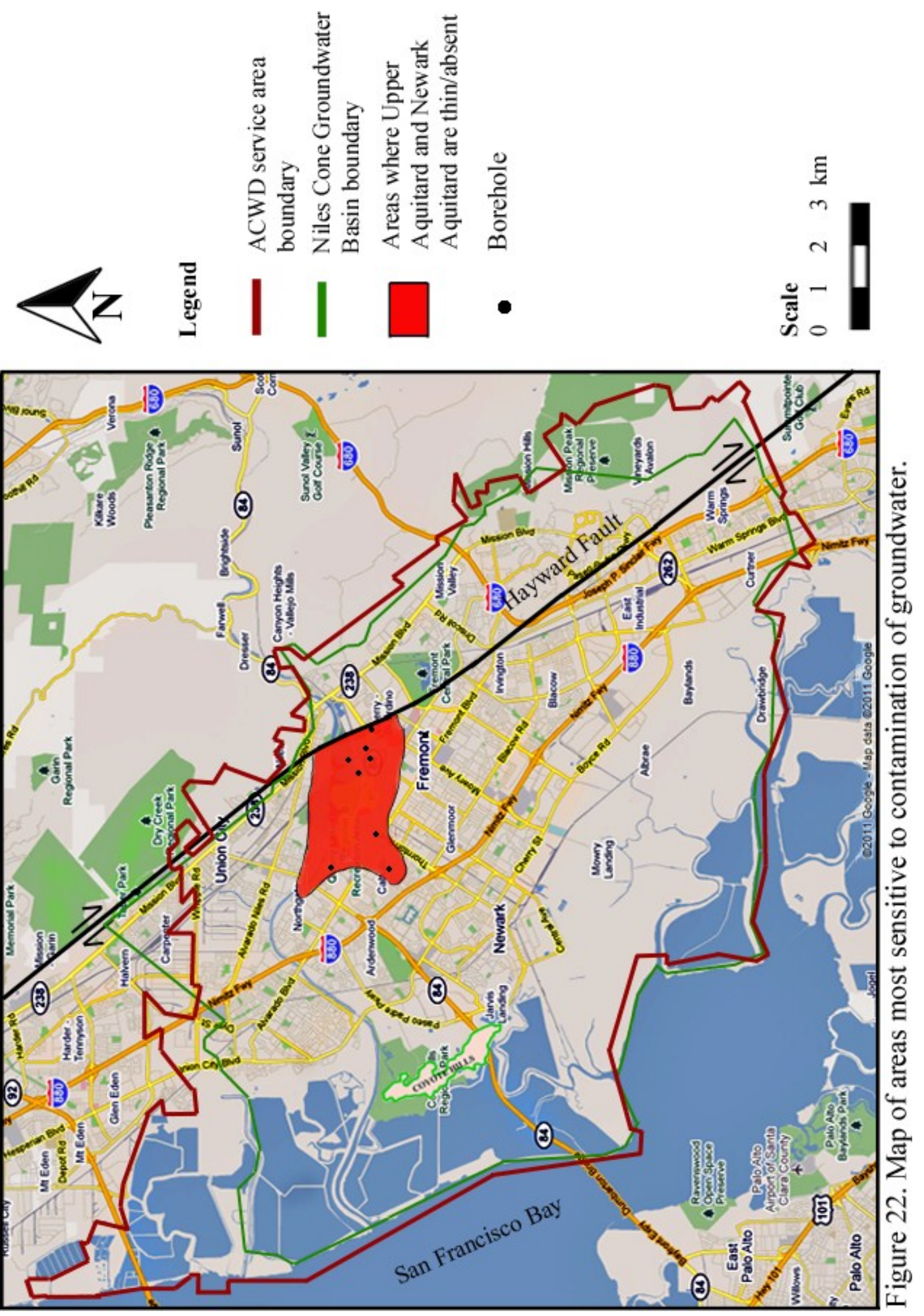




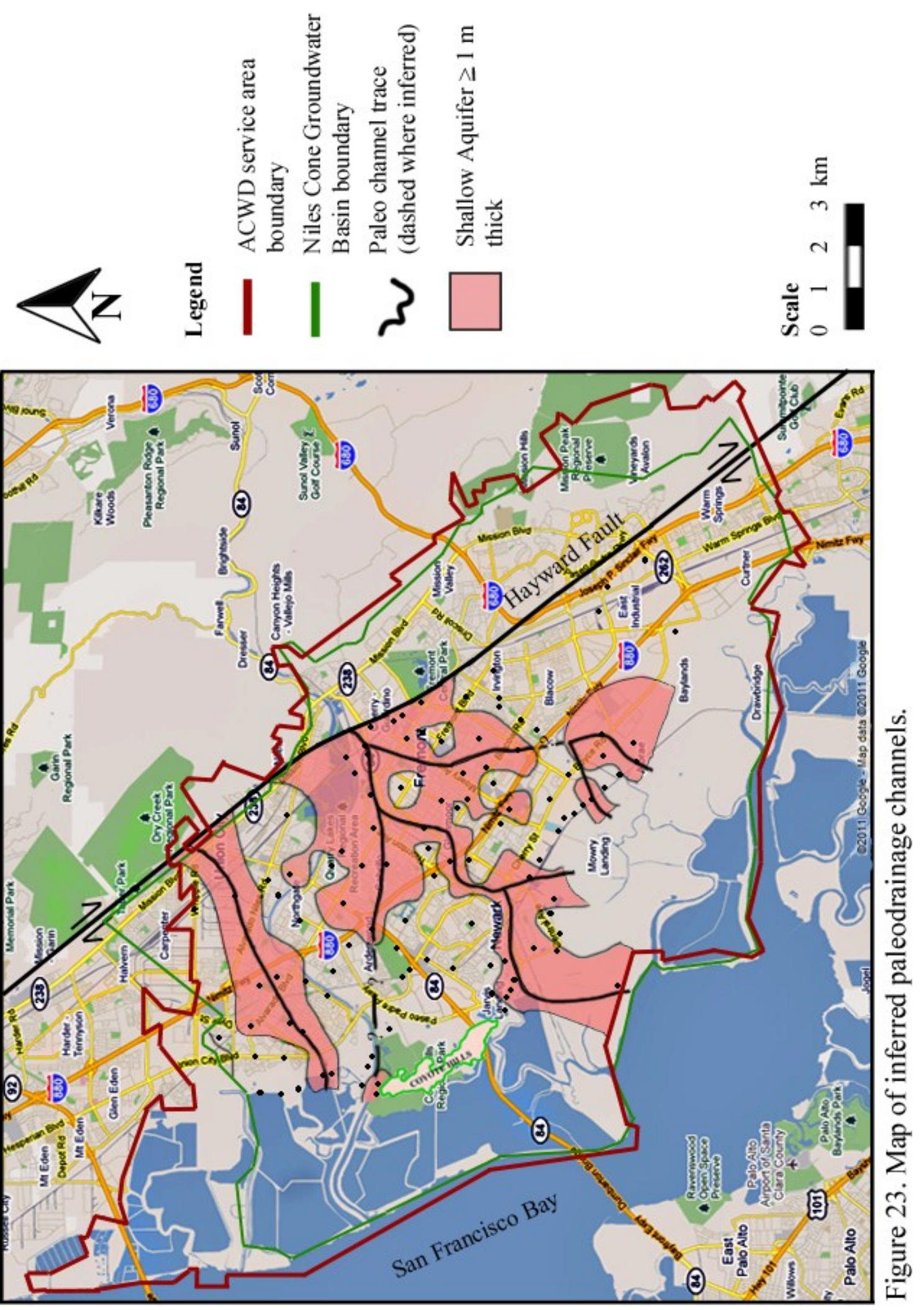


two ancestral streams, Alameda Creek and Dry Creek. Dry Creek in the north of the study area evidently flowed into San Francisco Bay following a single, primary pathway. The larger Alameda Creek flowed around the Coyote Hills to reach the Bay either to the north or to the south of the hills, having changed course over time. 


\section{CONCLUSION}

This study identified the Forebay area and its vicinity as the most sensitive to surface contamination in the Niles Cone Groundwater Basin. The Upper and Newark Aquitards in these areas were either thin or absent. Because the Shallow Aquifer deposits in these areas were either exposed at the ground surface or thinly covered with the Upper Aquitard and hydraulically connected to the underlying Newark Aquifer, potential surface contaminants could move largely unhindered to the underlying groundwaterproducing aquifers.

In addition, the study determined that the shallow, coarse-grained sediments were deposited by two paleo-stream channels, Dry Creek in the north, and Alameda Creek, the main stream channel in the Niles Cone Groundwater Basin. Some of this deposition occurred when the level of the Bay was significantly lower (as much as $12 \mathrm{~m}$ ) than at present. The Shallow Aquifer was absent east of the Coyote Hills and in the southern part of the study area. 


\section{REFERENCES CITED}

Alameda County Water District (ACWD), 2010a, Groundwater Monitoring Report, 60 p.

Alameda County Water District (ACWD), 2010b, Inland Saltwater Intrusion Monitoring Wells Project, Final Report, 24 p.

Alameda County Water District (ACWD), 2011a, Sources of Water Supply, www.acwd.org, 1 p.

Alameda County Water District (ACWD), 2011b, Survey Report on Groundwater Conditions, $37 \mathrm{p}$.

Alameda County Water District (ACWD), 2012, Survey Report on Groundwater Conditions, $37 \mathrm{p}$.

Atwater, B.F., Hedel, C.W., and Helley, E.J., 1977, Late Quaternary depositional history, Holocene sea level changes, and vertical crustal movement, southern San Francisco Bay, California: U.S. Geological Survey Professional Paper 1014, 15 p.

Becker, T., 2011, South Bay aqueduct. California Department of Water Resources, www.zone7.com/images/pdf_docs/sba_projects/sba_ppt_1-11.pdf, 43p.

Brown, R.D., 1990, Quaternary deformation, in Wallace, R.E., ed., The San Andreas Fault System, California: U.S. Geological Survey Professional Paper 1515, p. 83113.

California Department of Water Resources (CWDR), 1967, Evaluation of Groundwater Resources, South Bay, Appendix A: Geology: Bulletin No. 118-1, 153 p.

California Department of Water Resources (CWDR), 1968, Evaluation of Groundwater Resources, South Bay, Volume 1 Fremont Study Area: Bulletin No. 118-1, 117 p.

California Regional Water Quality Control Board (CRWQCB), 2003, A comprehensive Groundwater protection evaluation for the south San Francisco Bay basins, $251 \mathrm{p}$.

Food and Agriculture Organization of the United Nations (FAO), 1999, Global climate maps, using Koppen classification, www.fao.org, 1p.

Graham, S.A., McCloy, C., Ward, R., and Turner, R., 1984, Basin evolution during change from convergent to transform continental margin in Central California: AAPG Bulletin, v. 68, p 233-249. 
Koltermann, C.E., and Gorelick, S.M., 1992, Paleoclimate signature in terrestrial flood deposits: Science, v. 256, p. 1775-1782.

Maslonkowski, D.P., 1988, Hydrogeology of the San Leandro and San Lorenzo alluvial cones of the bay plain groundwater basin, Alameda County, California (MS Thesis): San Jose State University, 143 p.

National Oceanic \& Atmospheric Administration (NOAA), 2004, Climatography of the United States No. 20-1971-2000, 6 p.

Newhouse, M.W., Hanson, R.T., Wentworth, C.M., Everett, R.R., Williams, C.F., Tinsley, J.C., Noce, T.E., and Carkin, B.A., 2004, Geologic, water-chemistry, and hydrologic data from multiple-well monitoring sites and selected watersupply wells in the Santa Clara Valley, California, 1999-2003: U.S. Geological Survey Scientific Investigations Report 2004-5250, 134 p.

Poland, J. F., 1984, Guidebook to studies of land subsidence due to groundwater withdrawal: v. 40 of UNESCO Studies and Reports in Hydrology: Paris, France, United Nations Educational, Scientific and Cultural Organization, 305 p.

Rogers, J.D., and Figuers, S.H., 1992, Late Quaternary stratigraphy of the East Bay plain, in Borchardt, Glenn, and others, eds., Proceeding of the Second Conference in Earthquake Hazards in the Eastern San Francisco Bay Area, California: Department of Conservation, Division of Mines and Geology Special Publication 113, p 19-28.

U.S. Environmental Protection Agency (USEPA), 2009, National drinking water regulation: EPA 816-F-09-004, May 2009.

U.S. Geological Survey Geographic Names Information System (USGSGNIS), 1981, Hetch Hetchy aqueduct, http://geonames.usgs.gov/pls/gazpublic/getgooglemap? p_lat=37.6260417\&p_longi=-121.3699417\&fid=243393. 